\title{
Differential Inhibition of Neuronal Sodium Channel Subtypes by the General Anesthetic Isoflurane
}

\author{
Cheng Zhou, Kenneth W. Johnson, Karl F. Herold, and Hugh C. Hemmings, Jr. \\ Departments of Anesthesiology (C.Z., K.W.J., K.F.H., H.C.H.) and Pharmacology (H.C.H.), Weill Cornell Medicine, New York, \\ New York; and Laboratory of Anesthesia and Critical Care Medicine, Translational Neuroscience Center, West China Hospital of \\ Sichuan University, Chengdu, Sichuan, People's Republic of China (C.Z.)
}

Received November 18, 2018; accepted February 19, 2019

\begin{abstract}
Volatile anesthetics depress neurotransmitter release in a brain region- and neurotransmitter-selective manner by unclear mechanisms. Voltage-gated sodium channels $\left(\mathrm{Na}_{\mathrm{v}} \mathrm{s}\right)$, which are coupled to synaptic vesicle exocytosis, are inhibited by volatile anesthetics through reduction of peak current and modulation of gating. Subtype-selective effects of anesthetics on $\mathrm{Na}_{\mathrm{v}}$ might contribute to observed neurotransmitter-selective anesthetic effects on release. We analyzed anesthetic effects on $\mathrm{Na}^{+}$currents mediated by the principal neuronal $\mathrm{Na}_{\mathrm{v}}$ subtypes $\mathrm{Na}_{v} 1.1, \mathrm{Na}_{v} 1.2$, and $\mathrm{Na}_{v} 1.6$ heterologously expressed in ND7/23 neuroblastoma cells using whole-cell patch-clamp electrophysiology. Isoflurane at clinically relevant concentrations induced a hyperpolarizing shift in the voltage dependence of
\end{abstract}

steady-state inactivation and slowed recovery from fast inactivation in all three $\mathrm{Na}_{v}$ subtypes, with the voltage of halfmaximal steady-state inactivation significantly more positive for $\mathrm{Na}_{\mathrm{v}} 1.1(-49.7 \pm 3.9 \mathrm{mV})$ than for $\mathrm{Na}_{\mathrm{v}} 1.2(-57.5 \pm 1.2 \mathrm{mV})$ or $\mathrm{Na}_{\mathrm{v}} 1.6(-58.0 \pm 3.8 \mathrm{mV})$. Isoflurane significantly inhibited peak $\mathrm{Na}^{+}$current $\left(I_{\mathrm{Na}}\right)$ in a voltage-dependent manner: at a physiologically relevant holding potential of $-70 \mathrm{mV}$, isoflurane inhibited peak $I_{\mathrm{Na}}$ of $\mathrm{Na}_{\mathrm{v}} 1.2(16.5 \% \pm 5.5 \%)$ and $\mathrm{Na}_{\mathrm{v}} 1.6(18.0 \%$ $\pm 7.8 \%)$, but not of $\mathrm{Na}_{v} 1.1(1.2 \% \pm 0.8 \%)$. Since $\mathrm{Na}_{v}$ subtypes are differentially expressed both between neuronal types and within neurons, greater inhibition of $\mathrm{Na}_{v} 1.2$ and $\mathrm{Na}_{v} 1.6 \mathrm{com}-$ pared with $\mathrm{Na}_{v} 1.1$ could contribute to neurotransmitter-selective effects of isoflurane on synaptic transmission.

\section{Introduction}

Volatile anesthetics have been in clinical use for over 170 years, but their mechanisms of action are poorly understood (Hemmings et al., 2005). They have well described effects on multiple protein targets involved in neurotransmission, including ligand-gated and voltage-gated ion channels (Hemmings et al., 2005; Franks, 2006), but the contributions of these molecular actions to their specific neurophysiological effects are less clear. Volatile anesthetics induce a therapeutic state of unconsciousness, amnesia, and immobility, but they can also produce serious side effects, including cardiovascular and respiratory depression and developmental neurotoxicity (Hemmings et al., 2005; Franks, 2006; Jevtovic-Todorovic, 2016). Understanding the effect-specific cellular and molecular targets for volatile anesthetics is therefore critical for potential mechanism-based development of novel anesthetics or approaches to mitigating toxicities.

Voltage-gated $\mathrm{Na}^{+}$channels $\left(\mathrm{Na}_{\mathrm{v}} \mathrm{s}\right)$ are crucial for mediating cellular membrane excitability, including initiation and propagation of action potentials (APs) (Hodgkin and Huxley,

This work was supported by the National Institutes of Health National Institute of General Medical Sciences [Grant GM-58055] (to H.C.H.)] and the Weill Cornell Medicine Department of Anesthesiology.

https://doi.org/10.1124/jpet.118.254938.
1952; Catterall et al., 2005; Hu et al., 2009; Clay, 2013). They are also targets for the effects of volatile anesthetics (Rehberg et al., 1996; Hemmings, 2009; Herold and Hemmings, 2012; Herold et al., 2014; Covarrubias et al., 2015). Multiple $\mathrm{Na}_{\mathrm{v}}$ subtypes are inhibited by volatile anesthetics (Ouyang et al., 2003, 2009; Shiraishi and Harris, 2004; OuYang and Hemmings, 2007), which can lead to reduced presynaptic AP amplitude in rat calyceal neurons (Wu et al., 2004), isolated neurohypophysial nerve terminals (Ouyang et al., 2003), and inhibition of neurotransmitter release (Westphalen and Hemmings, 2003a, 2006; Wu et al., 2004). Modulation of $\mathrm{Na}_{\mathrm{v}}$ function also contributes to general anesthetic potency in vivo. Activation of $\mathrm{Na}_{\mathrm{v}}$ in the spinal cord by intrathecal infusion of veratridine reduces the immobilizing effect of isoflurane in rats; conversely, blocking $\mathrm{Na}_{\mathrm{v}}$ by intrathecal infusion of the highly selective $\mathrm{Na}_{\mathrm{v}}$ blocker tetrodotoxin (TTX) enhances the immobilizing effect of isoflurane (Zhang et al., 2008, 2010).

Volatile anesthetics inhibit neurotransmitter release in a brain region- and neurotransmitter-selective manner (Westphalen and Hemmings, 2006; Westphalen et al., 2010, 2011; Baumgart et al., 2015). For example, isoflurane inhibits release of glutamate more potently than release of GABA from cultured hippocampal neurons (Westphalen and Hemmings, 2006; Baumgart et al., 2015) and differentially inhibits neurotransmitter release between brain regions and the spinal cord (Westphalen et al., 2010, 2011). $\mathrm{Na}_{\mathrm{v}}$ subtypes

ABBREVIATIONS: AP, action potential; CNS, central nervous system; EPSC, excitatory postsynaptic current; $I_{\text {Na }}$, sodium current; MAC, minimum alveolar concentration; $\mathrm{Na}_{\mathrm{v}}$, voltage-gated sodium channel; TTX, tetrodotoxin; $\mathrm{V}_{1 / 2 \text { act }}$, voltage of half-maximal activation; $\mathrm{V}_{1 / 2 \text { inact }}$, voltage of halfmaximal inactivation. 
show subcellular, regional, and neurotransmitter-selective expression in the central nervous system (CNS) (Lai and Jan, 2006; Ogiwara et al., 2007; Lorincz and Nusser, 2008b; Johnson et al., 2017). Given their sensitivity to volatile anesthetics, the differential effects of anesthetics on neurotransmitter release might be explained by their selective inhibition of specific presynaptic $\mathrm{Na}_{\mathrm{v}}$ subtypes. Of the nine identified $\mathrm{Na}_{\mathrm{v}}$ subtypes $\left(\mathrm{Na}_{\mathrm{v}} 1.1-\mathrm{Na}_{\mathrm{v}} 1.9\right), \mathrm{Na}_{\mathrm{v}} 1.1, \mathrm{Na}_{\mathrm{v}} 1.2$, and $\mathrm{Na}_{\mathrm{v}} 1.6$ are highly expressed in the CNS (Black and Waxman, 1996; Wood and Baker, 2001). Volatile anesthetics display differential subtype-selective inhibition of $\mathrm{Na}_{\mathrm{v}} 1.2$ (one of the predominant brain subtypes), $\mathrm{Na}_{\mathrm{v}} 1.4$ (the predominant skeletal muscle subtype), and $\mathrm{Na}_{\mathrm{v}} 1.5$ (the predominant cardiac subtype) (OuYang and Hemmings, 2007). However, the role of subtype-selective effects of volatile anesthetics on neuronal $\mathrm{Na}_{\mathrm{v}}$ subtypes in their presynaptic effects is unknown. We therefore examined the effects of isoflurane on the three major neuronal $\mathrm{Na}_{\mathrm{v}}$ subtypes expressed in the adult mammalian brain using whole-cell patch-clamp electrophysiology in a homogenous neuronal cell line. Selective inhibition of $\mathrm{Na}_{\mathrm{v}}$ subtypes would provide a neurophysiological basis for $\mathrm{Na}_{\mathrm{v}}$ inhibition in the region- and neurotransmitter-selective effects of volatile anesthetics on neuronal excitability and synaptic transmission.

\section{Materials and Methods}

Materials. Isoflurane was obtained from Abbott Laboratories (North Chicago, IL). TTX was from Sankyo Kasei (Tokyo, Japan). All other compounds for solution preparation were from Sigma-Aldrich (St. Louis, MO).

cDNA Constructs. $\mathrm{Na}^{+}$currents from three neuronal $\mathrm{Na}_{\mathrm{v}}$ subtypes $\left(\mathrm{Na}_{\mathrm{v}} 1.1, \mathrm{Na}_{\mathrm{v}} 1.2\right.$, and $\left.\mathrm{Na}_{\mathrm{v}} 1.6\right)$ were recorded and analyzed by heterologous expression of the respective subtype in a neuronal background using the ND7/23 neuroblastoma cell line (Herold et al., 2009). Each subtype was rendered TTX resistant by mutation of a single amino acid located in the extracellular toxin binding domain that has been shown to have no effect on gating properties, channel kinetics, or anesthetic sensitivity (Herzog et al., 2003; Leffler et al., 2005; Cestèle et al., 2013; Purtell et al., 2015). We refer to the mutant channels as $\mathrm{Na}_{\mathrm{v}} 1.1, \mathrm{Na}_{\mathrm{v}} 1.2$, and $\mathrm{Na}_{\mathrm{v}} 1.6$ below. Wild-type human $\mathrm{Na}_{\mathrm{v}} 1.1$ (accession number NM_001165963), kindly provided by A. L. George, Jr. (Northwestern University, Evanston, IL), was mutated to F383S (Cestèle et al., 2013). Wild-type rat $\mathrm{Na}_{\mathrm{v}} 1.2$ (accession number NM_012647), kindly provided by W. Catterall (University of Washington, Seattle, WA), was mutated to F385S (Leffler et al., 2005; Purtell et al., 2015). Wild-type mouse $\mathrm{Na}_{\mathrm{v}} 1.6$ (accession number NM_001077499), kindly provided by S. G. Waxman (Yale University, New Haven, CT), was mutated to Y371S (Herzog et al., 2003).

Cell Culture and Transfection. Rodent ND7/23 neuroblastoma cells (Sigma-Aldrich) were plated on 12-mm glass coverslips and incubated at $37^{\circ} \mathrm{C}$ in a humidified atmosphere of $5 \% \mathrm{CO}_{2} / 95 \% \mathrm{O}_{2}$ in Dulbecco's modified Eagle's medium supplemented with $10 \%(\mathrm{v} / \mathrm{v})$ fetal bovine serum, $2 \mathrm{mM}$ L-glutamine, $100 \mathrm{U} / \mathrm{ml}$ penicillin, and $100 \mu \mathrm{g} / \mathrm{ml}$ streptomycin (Sigma-Aldrich). This cell line provides a neuronal background for expression of $\mathrm{Na}_{\mathrm{v}}$ by providing critical factors such as auxiliary subunits that facilitate functional expression of the channel protein (Herold et al., 2009). Transfected TTX-resistant $\mathrm{Na}_{\mathrm{v}}$ subtypes were studied in the presence of $250 \mathrm{nM}$ TTX to block endogenous $\mathrm{Na}^{+}$currents (Herold et al., 2009; Purtell et al., 2015). ND7/23 cells were cotransfected with $2.5 \mu \mathrm{g} \mathrm{Na}$ 1.1, $\mathrm{Na}_{\mathrm{v}} 1.2$, or $\mathrm{Na}_{\mathrm{v}} 1.6$ cDNA together with $0.7 \mu \mathrm{g}$ pEGFP-N1 cDNA (Clontech, Mountain View, CA) using Lipofectamine LTX (Invitrogen, Carlsbad, CA) to allow identification of enhanced green fluorescent protein-transfected cells by fluorescence microscopy. Electrophysiological studies were conducted 48 hours after transfection.

Measurement of Sodium Currents. Whole-cell patch-clamp recordings of $\mathrm{Na}^{+}$currents $\left(I_{\mathrm{Na}}\right)$ were obtained at room temperature $\left(23-24^{\circ} \mathrm{C}\right.$ ) using an Axopatch 200B amplifier (Axon Instruments, Burlingame, CA) digitized with a Digidata 1321A interface and analyzed using pClamp 10.2 software (Axon Instruments). Wholecell $I_{\mathrm{Na}}$ was sampled at $50 \mathrm{kHz}$ and low-pass filtered at $10 \mathrm{kHz}$. Pipettes were filled with internal solution as follows: $120 \mathrm{mM} \mathrm{CsF}$, $10 \mathrm{mM} \mathrm{NaCl}, 10 \mathrm{mM}$ HEPES, $10 \mathrm{mM}$ EGTA, $10 \mathrm{mM}$ TEA-Cl, $1 \mathrm{mM}$ $\mathrm{CaCl}_{2}$, and $1 \mathrm{mM} \mathrm{MgCl}_{2}$ adjusted to $\mathrm{pH} 7.3$ (by $\mathrm{CsOH}$ ) and to $334 \mathrm{mOsm} / \mathrm{kg}$ (with sucrose). Pipette resistance when filled was 1.5-3.0 $\mathrm{M} \Omega$. The external solution contained the following: $140 \mathrm{mM}$ $\mathrm{NaCl}, 10 \mathrm{mM}$ HEPES, $3 \mathrm{mM} \mathrm{KCl}, 1 \mathrm{mM} \mathrm{MgCl} 2,2 \mathrm{mM} \mathrm{CaCl}_{2}, 20 \mathrm{mM}$ TEA-Cl, $5 \mathrm{mM}$ D-glucose, and $0.00025 \mathrm{mM}$ TTX adjusted to $\mathrm{pH} 7.4$ (with $\mathrm{NaOH}$ ) and to $330 \mathrm{mOsm} / \mathrm{kg}$ (with sucrose). Liquid-junction potential was not corrected. To minimize space-clamp and series resistance errors, only cells expressing 1-8 nA peak current were analyzed. Capacitance transients were cancelled and voltage error was minimized using 70\%-80\% series resistance correction. Series resistance was typically $2-5 \mathrm{M} \Omega$; data were discarded if series resistance was $>8 \mathrm{M} \Omega$. Recordings began 5 minutes after attaining the whole-cell patch to allow equilibration of pipette solution and cytosol. Leak currents were subtracted using the P/4 method (Bezanilla and Armstrong, 1977) applied after test pulses. Stimulation protocols were applied in control external solution containing $250 \mathrm{nM}$ TTX, and again after a 2-minute perfusion with external solution containing isoflurane.

Simulation of Isoflurane Effects on APs. A computational model using NEURON software 7.4 (http://www.neuron.yale.edu/ neuron/) was used to simulate the effects of isoflurane on $\mathrm{Na}_{\mathrm{v}} 1.1$, $\mathrm{Na}_{\mathrm{v}} 1.2$, and $\mathrm{Na}_{\mathrm{v}} 1.6$ function by adjusting reported $\mathrm{Na}_{\mathrm{v}}$ electrophysiological parameters (Herzog et al., 2001) to the parameters we obtained. Simulation of APs was modified from the model (Akemann et al., 2009) to be mediated by $\mathrm{Na}_{\mathrm{v}} 1.1, \mathrm{Na}_{\mathrm{v}} 1.2$, or $\mathrm{Na}_{\mathrm{v}} 1.6$, with soma length and width set as $25 \mu \mathrm{m}$ and $\mathrm{R}_{\mathrm{a}}$ as $80 \Omega / \mathrm{cm}$. The electrophysiological properties of original pas (passive) and hh (Hodgkin-Huxley) channels were set to default NEURON values, and resting membrane potential of the soma was set at $-70 \mathrm{mV}$. Because experimental recordings were performed at 23 to $24^{\circ} \mathrm{C}$, temperature-dependent effects of isoflurane on simulated $\mathrm{Na}_{\mathrm{v}}$ kinetics were modeled as described (Collins and Rojas, 1982) based on the kinetic model of $\mathrm{m}^{3} \mathrm{~h}$, where $\mathrm{Q}_{10}=2.34$ for $\mathrm{m}$ and $\mathrm{Q}_{10}=2.9$ for $\mathrm{h}$ to simulate APs mediated by $\mathrm{Na}_{\mathrm{v}} 1.1, \mathrm{Na}_{\mathrm{v}} 1.2$, or $\mathrm{Na}_{\mathrm{v}} 1.6$ at $37^{\circ} \mathrm{C}$. The relationship between AP amplitude and probability of transmitter release was modeled using a previously established nerve terminal model (Graham and Redman, 1994). The simulation of excitatory postsynaptic currents (EPSCs) was modified from Graham et al. (2001) and based on the observed effects of isoflurane on AP amplitude and firing frequency mediated by $\mathrm{Na}_{\mathrm{v}} 1.1, \mathrm{Na}_{\mathrm{v}} 1.2$, or $\mathrm{Na}_{\mathrm{v}} 1.6$ at $37^{\circ} \mathrm{C}$. The control presynaptic stimulus was 100 milliseconds at $100 \mathrm{~Hz}$. The stimulus under isoflurane was based on the effects of isoflurane on AP frequency mediated by each $\mathrm{Na}_{\mathrm{v}}$ subtype.

Isoflurane Application. A saturated stock solution of isoflurane (Abbott Laboratories) in external solution (12 to $13 \mathrm{mM}$ ) was diluted to the desired final concentrations in gas-tight glass syringes. For electrophysiological recording, isoflurane solutions were perfused using a pressure-driven microperfusion system (ALA BPS-8; ALA Scientific, Westbury, NY) with the perfusion pipette tip positioned 100-150 $\mu \mathrm{m}$ away from the recorded cell. Isoflurane concentrations sampled at the perfusion pipette tip were determined by gas chromatography using a Shimadzu GC-2010 Plus gas chromatograph (Shimadzu, Tokyo, Japan) after extraction into octane (Herold et al., 2009). Isoflurane $(0.3 \mathrm{mM})$ was used as the predicted minimum alveolar concentration (MAC; equivalent to the $\mathrm{EC}_{50}$ for immobilization) in rats after temperature adjustment to $23^{\circ} \mathrm{C}$ (Taheri et al., 1991; Ouyang et al., 2009).

Data and Statistical Analysis. Data were analyzed using GraphPad Prism 6 (GraphPad Software Inc., San Diego, CA) and 
SPSS 22.0 (SPSS Science Software Inc., Chicago, IL). Conductance (G) values were derived from the $\mathrm{I}-\mathrm{V}$ relationship using the equation $\mathrm{G}=$ $\mathrm{I} /\left(\mathrm{V}-\mathrm{V}_{\text {rev }}\right)$, where $\mathrm{I}$ is the peak $I_{\mathrm{Na}}$ at a given voltage $(\mathrm{V})$ and $\mathrm{V}_{\text {rev }}$ is the measured $\mathrm{Na}^{+}$reversal potential. Voltage of half-maximal activation $\left(\mathrm{V}_{1 / 2 \text { act }}\right)$ was obtained by fitting data for each cell to a Boltzmann equation of the form $\mathrm{G} / \mathrm{G}_{\max }=1 /\left[1+\exp \left(\mathrm{V}_{1 / 2 \text { act }}-\mathrm{V} / \mathrm{k}\right)\right]$, where $\mathrm{G} / \mathrm{G}_{\max }$ is the normalized fractional conductance and $\mathrm{k}$ is the slope factor. Voltage of half-maximal fast inactivation $\left(\mathrm{V}_{1 / 2 \text { inact }}\right)$ was measured by fitting normalized steady-state $I_{\mathrm{Na}}$ values to a Boltzmann equation of the form $I_{\mathrm{Na}} / I_{\mathrm{Na}} \max =1 /\left[1+\exp \left(\mathrm{V}_{1 / 2 \text { inact }}-\mathrm{V} / \mathrm{k}\right)\right]$. Halfmaximal inhibitory concentration $\left(\mathrm{IC}_{50}\right)$ values were obtained by leastsquares fitting to the Hill equation: $\mathrm{Y}=1 /\left(1+10\left(\left[\log \mathrm{IC}_{50}-\mathrm{X}\right] \times \mathrm{h}\right)\right.$, where $\mathrm{Y}$ is the effect, $\mathrm{X}$ is the measured concentration of isoflurane, and $\mathrm{h}$ is the Hill slope. Time course data were fitted to the monoexponential function $\mathrm{Y}=\exp (-\tau \times \mathrm{n})+\mathrm{A}_{\mathrm{P}}$, where $\tau$ is the time constant, $A_{P}$ is the plateau, and $n$ is stimulus number based on complete recovery time. Data (expressed as means \pm S.D.) were assessed for normality using the Shapiro-Wilk test and analyzed using the twotailed paired $t$ test or ANOVA with post hoc testing as indicated, with $P<0.05$ as the threshold for statistical significance.

\section{Results}

Neuronal $\mathrm{Na}_{\mathrm{v}}$ Subtypes have Distinct Electrophysiological Properties. Voltage of half-maximal activation $\left(\mathrm{V}_{1 / 2 \mathrm{act}}\right)$ did not differ between $\mathrm{Na}_{\mathrm{v}} 1.1, \mathrm{Na}_{\mathrm{v}} 1.2$, and $\mathrm{Na}_{\mathrm{v}} 1.6$ under control conditions (Table 1). Voltage of half-maximal inactivation $\left(\mathrm{V}_{1 / 2 \text { inact }}\right)$ for $\mathrm{Na}_{\mathrm{v}} 1.1$ was significantly more depolarized than for $\mathrm{Na}_{\mathrm{v}} 1.2$ or $\mathrm{Na}_{\mathrm{v}} 1.6$ (Table 1). From a hyperpolarized holding potential of $-100 \mathrm{mV}$, recovery from fast inactivation $(\tau)$ was significantly slower for $\mathrm{Na}_{\mathrm{v}} 1.2$ than for $\mathrm{Na}_{\mathrm{v}}$ 1.6. From a physiologic holding potential of $-70 \mathrm{mV}, \tau$ for recovery was significantly slower for $\mathrm{Na}_{\mathrm{v}} 1.2$ than for $\mathrm{Na}_{\mathrm{v}} 1.1$ or $\mathrm{Na}_{\mathrm{v}} 1.6$ (Table 2).

Isoflurane Does Not Affect Sodium Channel Activation. Channel activation was evoked by a series of 10-millisecond voltage steps from -70 to $+60 \mathrm{mV}$ preceded by a 100 millisecond prepulse to $-100 \mathrm{mV}$ (Purtell et al., 2015). Isoflurane $(0.48 \pm 0.03 \mathrm{mM} ; 1.6 \mathrm{MAC})$ did not significantly affect current-voltage (I-V) relationships or voltage dependence of half-maximal activation $\left(\mathrm{V}_{1 / 2 \text { act }}\right)$ of $\mathrm{Na}_{\mathrm{v}} 1.1(n=6)$, $\mathrm{Na}_{\mathrm{v}} 1.2(n=6)$, or $\mathrm{Na}_{\mathrm{v}} 1.6(n=5)$ (all $P>0.05$ by paired twotailed $t$ test) (Fig. 1). Peak $I_{\mathrm{Na}}$ was elicited at $0 \mathrm{mV}$ for all three $\mathrm{Na}_{\mathrm{v}}$ subtypes for both control and isoflurane conditions. Values of $\mathrm{V}_{1 / 2 \text { act }}$ for the control and 1.6 MAC isoflurane conditions are shown in Table 1.

Isoflurane Enhances Voltage-Dependent Inactivation. The effect of isoflurane on steady-state fast inactivation was determined by a double pulse protocol with a 300-millisecond prepulse ranging from -110 to $-10 \mathrm{mV}$ in $10-\mathrm{mV}$ steps, followed by depolarization to $0 \mathrm{mV}$ to elicit peak $I_{\mathrm{Na}}$. Normalized $I_{\mathrm{Na}} / I_{\mathrm{Na}}$ max values reflected the fraction of channels inactivated during the prepulse. Isoflurane $(0.48 \pm 0.03 \mathrm{mM} ; \sim 1.6 \mathrm{MAC})$ shifted the voltage dependence of steady-state inactivation toward more hyperpolarized potentials for $\mathrm{Na}_{\mathrm{v}} 1.1(n=6), \mathrm{Na}_{\mathrm{v}} 1.2(n=6)$, and $\mathrm{Na}_{\mathrm{v}} 1.6(n=5)$ (all $P<0.05$, by paired $t$ test) (Fig. 2, G-I). The magnitude of the voltage shift was similar for all three $\mathrm{Na}_{\mathrm{v}}$ subtypes tested (Table 1).

Isoflurane Differentially Inhibited Peak $\boldsymbol{I}_{\mathbf{N a}}$. Inhibition by isoflurane was greater for $\mathrm{Na}_{\mathrm{v}} 1.2$ and $\mathrm{Na}_{\mathrm{v}} 1.6$ than for $\mathrm{Na}_{\mathrm{v}} 1.1$ at a physiologically relevant holding potential of $-70 \mathrm{mV}$. We tested the degree of $\mathrm{Na}_{\mathrm{v}}$ inhibition from holding potentials $\left(\mathrm{V}_{\mathrm{h}}\right)$ of $-120,-110$, or $-70 \mathrm{mV}$ or $\mathrm{V}_{1 / 2 \text { inact }}$ (voltage of half-maximal inactivation measured for each individual cell prior to the control recording). $\mathrm{V}_{1 / 2 \text { inact }}$ was $-51.2 \pm$ $1.2,-58.8 \pm 1.8$, or $-59.0 \pm 1.3 \mathrm{mV}$ for $\mathrm{Na}_{\mathrm{v}} 1.1, \mathrm{Na}_{\mathrm{v}} 1.2$, or $\mathrm{Na}_{\mathrm{v}} 1.6$, respectively (Fig. 3). From a holding potential of $-120 \mathrm{mV}$, isoflurane $(0.49 \pm 0.03 \mathrm{mM} ; 1.6 \mathrm{MAC})$ did not inhibit peak $I_{\mathrm{Na}}$ for any $\mathrm{Na}_{\mathrm{v}}$ subtype. From a holding potential of $-110 \mathrm{mV}$, isoflurane inhibited peak $I_{\mathrm{Na}}$ of $\mathrm{Na}_{\mathrm{v}} 1.2$ by $8.9 \% \pm$ $2.9 \%$ and of $\mathrm{Na}_{\mathrm{v}} 1.6_{\mathrm{R}}$ by $8.8 \% \pm 3.9 \%$, whereas $\mathrm{Na}_{\mathrm{v}} 1.1$ was not significantly inhibited (Fig. 4). From a physiologic holding potential of $-70 \mathrm{mV}$, isoflurane inhibited peak $I_{\mathrm{Na}}$ of $\mathrm{Na}_{\mathrm{v}} 1.2$ by $16.5 \% \pm 5.5 \%$ and of $\mathrm{Na}_{\mathrm{v}} 1.6$ by $18.0 \% \pm 7.8 \%$, with no effect on $\mathrm{Na}_{\mathrm{v}} 1.1$. From a holding potential of $\mathrm{V}_{1 / 2 \text { inact }}$, isoflurane significantly inhibited peak $I_{\mathrm{Na}}$ of all three $\mathrm{Na}_{\mathrm{v}}$ subtypes to a similar extent (by $\sim 30 \%$ ). The concentration-dependent inhibition of peak $I_{\mathrm{Na}}$ by isoflurane was well fitted to a Hill equation, and potency for inhibition was voltage dependent (Fig. 5, A-C). From a holding potential of $-70 \mathrm{mV}, \mathrm{Na}_{\mathrm{v}} 1.2$ and $\mathrm{Na}_{\mathrm{v}} 1.6$ were more sensitive to isoflurane $\left(\mathrm{IC}_{50}=1.0 \pm 0.2\right.$ and $1.1 \pm 0.1 \mathrm{mM}$, respectively) compared with $\mathrm{Na}_{\mathrm{v}} 1.1\left(\mathrm{IC}_{50}=\right.$ $2.0 \pm 0.1 \mathrm{mM} ; P<0.05$ by ANOVA, Fig. 5). From a holding potential of $\mathrm{V}_{1 / 2 \text { inact }}$, the $\mathrm{IC}_{50}$ values of isoflurane for all three $\mathrm{Na}_{\mathrm{v}}$ subtypes were similar $\left(0.9 \pm 0.2 \mathrm{mM}\right.$ for $\mathrm{Na}_{\mathrm{v}} 1.1,0.8 \pm$ $0.2 \mathrm{mM}$ for $\mathrm{Na}_{\mathrm{v}} 1.2$, and $0.9 \pm 0.2 \mathrm{mM}$ for $\mathrm{Na}_{\mathrm{v}} 1.6 ; P>0.05$ by ANOVA).

Isoflurane Differential Affects Recovery from Fast Inactivation. Neuronal firing frequency depends in part on the speed of $\mathrm{Na}_{\mathrm{v}}$ gating through its resting, open, and inactivated states, which is voltage dependent. We measured the effects of isoflurane on the time course of recovery from the fast-inactivated state. Peak $I_{\mathrm{Na}}$ was recorded in response to two 5-millisecond pulses to $0 \mathrm{mV}$, where the duration between pulses varied from 1 to 200 milliseconds. Recovery time courses were well fitted by a monoexponential function in control and isoflurane conditions, indicating that channels predominantly entered a single fast-inactivated state. Isoflurane $(0.58 \pm 0.04 \mathrm{mM} ; 1.9 \mathrm{MAC})$ slowed the recovery time

TABLE 1

Effects of isoflurane on voltage-dependent activation and inactivation of neuronal $\mathrm{Na}_{\mathrm{v}}$ subtypes

Data are expressed as means \pm S.D. Numbers in parentheses are the percentage change compared with the control.

\begin{tabular}{|c|c|c|c|c|c|c|}
\hline \multirow{2}{*}{ Subtype } & \multicolumn{3}{|c|}{$\mathrm{V}_{1 / 2 \text { act }}$} & \multicolumn{3}{|c|}{$\mathrm{V}_{1 / 2 \text { inact }}$} \\
\hline & CTL & ISO & $\Delta$ & CTL & ISO & $\Delta$ \\
\hline & & & & $m V$ & & \\
\hline $\begin{array}{l}\mathrm{Na}_{\mathrm{v}} 1.1 \\
\mathrm{Na}_{\mathrm{v}} 1.2 \\
\mathrm{Na}_{\mathrm{v}} 1.6\end{array}$ & $\begin{array}{l}-14.4 \pm 3.4 \\
-15.8 \pm 1.4 \\
-15.3 \pm 2.0\end{array}$ & $\begin{array}{l}-15.4 \pm 3.3 \\
-16.5 \pm 0.8 \\
-16.3 \pm 2.1\end{array}$ & $\begin{array}{l}-1.0 \pm 1.1(7) \\
-0.6 \pm 0.7(4) \\
-0.9 \pm 0.5(7)\end{array}$ & $\begin{array}{l}-49.7 \pm 3.9^{*, * *} \\
-57.5 \pm 1.2^{*} \\
-58.0 \pm 3.8^{* *}\end{array}$ & $\begin{array}{l}-54.6 \pm 4.9^{* * *} \\
-61.3 \pm 1.4^{* * *} \\
-64.2 \pm 5.3^{* * *}\end{array}$ & $\begin{array}{l}-4.9 \pm 2.7(10) \\
-3.8 \pm 1.7(7) \\
-6.2 \pm 2.3(11)\end{array}$ \\
\hline
\end{tabular}

CTL, control; ISO, isoflurane at $0.48 \pm 0.03 \mathrm{mM}(\sim 1.6 \mathrm{MAC})$

$* P<0.05\left(\mathrm{Na}_{\mathrm{v}} 1.1\right.$ vs. $\left.\mathrm{Na}_{\mathrm{v}} 1.2\right) ; * * P<0.05\left(\mathrm{Na}_{\mathrm{v}} 1.1\right.$ vs. $\left.\mathrm{Na}_{\mathrm{v}} 1.6\right)$; $* * * P<0.05$ (CTL vs. ISO). 
TABLE 2

Effects of isoflurane on neuronal $\mathrm{Na}_{\mathrm{v}}$ subtype recovery from fast inactivation

Data are expressed as means \pm S.D. Numbers in parentheses are the percentage change compared with the control.

\begin{tabular}{|c|c|c|c|c|c|c|}
\hline \multirow{2}{*}{ Subtype } & \multicolumn{3}{|c|}{$\tau_{\text {recovery }}, \mathrm{V}_{\mathrm{h}}-100 \mathrm{mV}$} & \multicolumn{3}{|c|}{$\tau_{\text {recovery }}, \mathrm{V}_{\mathrm{h}}-70 \mathrm{mV}$} \\
\hline & CTL & ISO & $\Delta$ & CTL & ISO & $\Delta$ \\
\hline & & & & $m s$ & & \\
\hline $\mathrm{Na}_{\mathrm{v}} 1.1$ & $1.6 \pm 0.2$ & $1.9 \pm 0.3^{* *}$ & $0.3 \pm 0.2(16)$ & $6.1 \pm 0.8^{* * *}$ & $7.4 \pm 1.2^{* *}$ & $1.3 \pm 0.7(21)$ \\
\hline $\mathrm{Na}_{\mathrm{v}} 1.2$ & $1.9 \pm 0.5^{*}$ & $2.2 \pm 0.6^{* *}$ & $0.3 \pm 0.2(17)$ & $8.4 \pm 2.4^{*, * * * *}$ & $10.1 \pm 2.9 * *$ & $1.7 \pm 0.8(20)$ \\
\hline $\mathrm{Na}_{\mathrm{v}} 1.6$ & $1.2 \pm 0.2^{*}$ & $1.7 \pm 0.2^{* *}$ & $0.4 \pm 0.3(38)$ & $4.7 \pm 0.7^{*}$ & $6.6 \pm 1.0^{* *}$ & $1.8 \pm 0.4(39)$ \\
\hline
\end{tabular}

CTL, control; ISO, isoflurane at $0.58 \pm 0.04 \mathrm{mM}(\sim 1.9 \mathrm{MAC}) ; \tau_{\text {recovery }}$, half-time for recovery form inactivation; $\mathrm{V}_{\mathrm{h}}$, holding potential.

$* P<0.05\left(\mathrm{Na}_{\mathrm{v}} 1.2\right.$ vs. $\left.\mathrm{Na}_{\mathrm{v}} 1.6\right) ; * * P<0.05\left(\mathrm{CTL}\right.$ vs. ISO); $* * * P<0.05\left(\mathrm{Na}_{\mathrm{v}} 1.1\right.$ vs. $\left.\mathrm{Na}_{\mathrm{v}} 1.2\right)$

course ( $\mathrm{r}_{\text {ecovery }}$ ) of $\mathrm{Na}_{\mathrm{v}} 1.1, \mathrm{Na}_{\mathrm{v}} 1.2$, and $\mathrm{Na}_{\mathrm{v}} 1.6$ (Table 2). Isoflurane significantly increased the time required for full channel recovery at a hyperpolarized holding potential of $-100 \mathrm{mV}$ (Fig. 6) in $\mathrm{Na}_{\mathrm{v}} 1.1, \mathrm{Na}_{\mathrm{v}} 1.2$, and $\mathrm{Na}_{\mathrm{v}} 1.6$ (all $n=6$, paired two-tailed $t$ test). These effects were enhanced at a holding potential of $-70 \mathrm{mV}$ in $\mathrm{Na}_{\mathrm{v}} 1.1, \mathrm{Na}_{\mathrm{v}} 1.2$, and $\mathrm{Na}_{\mathrm{v}} 1.6$ (all $n=6$, paired $t$ test).

Effects of Isoflurane on Simulated APs and Synaptic Transmission. We used the NEURON algorithm to simulate the voltage dependence of $\mathrm{Na}_{\mathrm{v}} 1.1-, \mathrm{Na}_{\mathrm{v}} 1.2-$, and
A

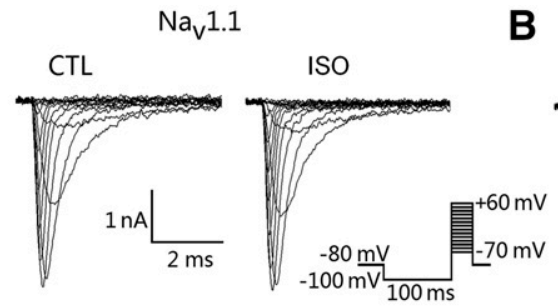

B

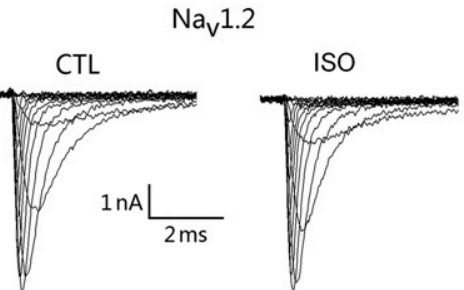

C

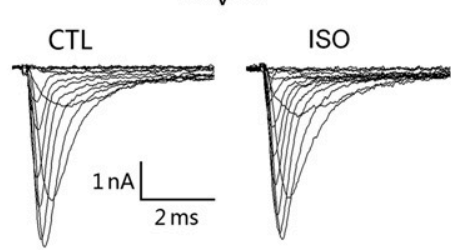

E
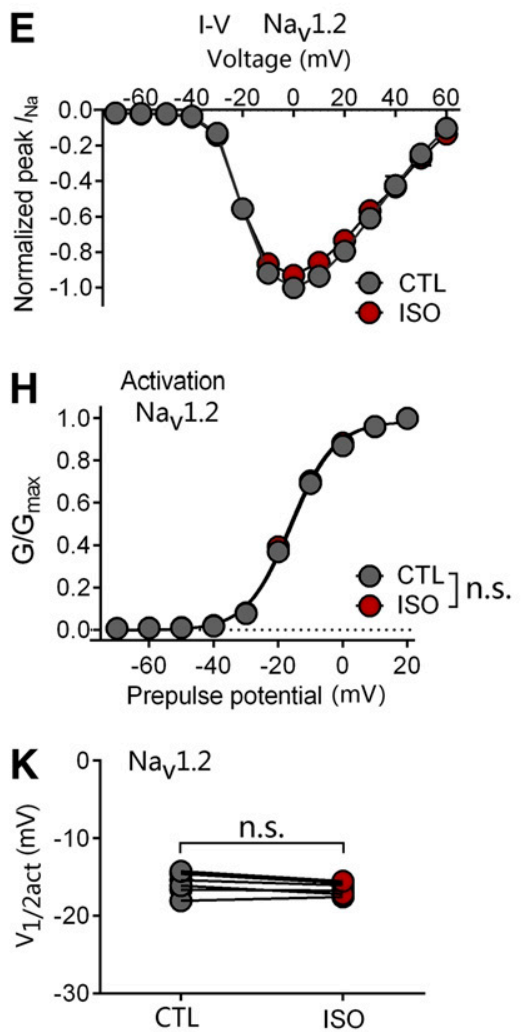

$\mathbf{F}$
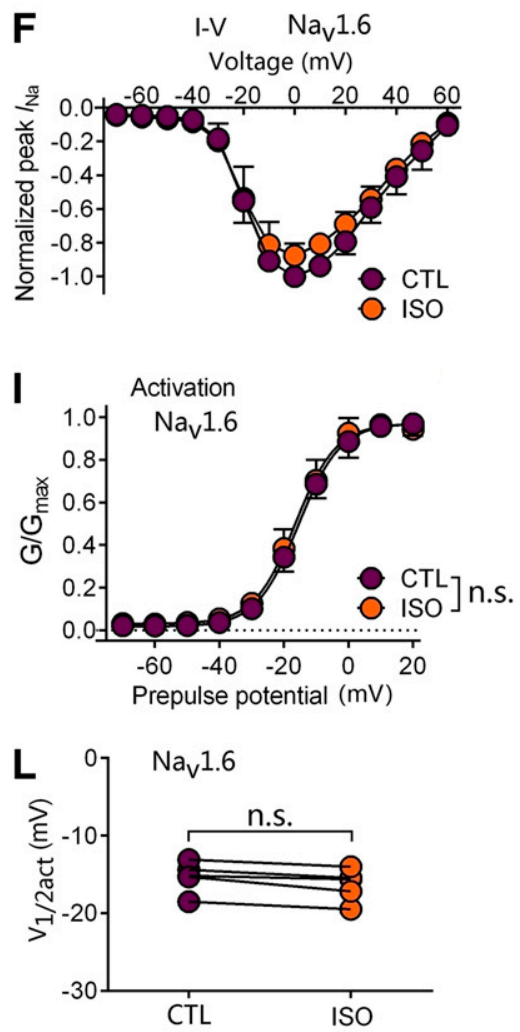

Fig. 1. Effects of isoflurane on $\mathrm{Na}_{\mathrm{v}}$ activation. Isoflurane did not significantly affect the voltage of half-maximal activation $\left(\mathrm{V}_{1 / 2 \mathrm{act}}\right)$ of $\mathrm{Na}_{\mathrm{v}} 1.1(n=6)$, $\mathrm{Na}_{\mathrm{v}} 1.2(n=6)$, or $\mathrm{Na}_{\mathrm{v}} 1.6(n=5)$. See Table 1 for individual values. Channels were activated by a series of voltage steps from -70 to $+60 \mathrm{mV}$ preceded by a 100-millisecond prepulse to $-100 \mathrm{mV}$. (A-C) Representative traces for the control (CTL) or isoflurane (ISO) (0.48 mM, 1.6 MAC) for Na $1.1, \mathrm{Na}_{\mathrm{v}} 1.2$, and $\mathrm{Na}_{\mathrm{v}}$ 1.6. (D-F) Current-voltage relationships (I-V) for $\mathrm{Na}_{\mathrm{v}} 1.1, \mathrm{Na}_{\mathrm{v}} 1.2$, and $\mathrm{Na}_{\mathrm{v}} 1.6$. (G-I) Activation curves for $\mathrm{Na}_{\mathrm{v}} 1.1, \mathrm{Na}_{\mathrm{v}} 1.2$, and $\mathrm{Na}_{\mathrm{v}} 1.6$, for the control or isoflurane $\left(0.48 \mathrm{mM}\right.$ isoflurane). (J-L) Voltage of half-maximum activation $\left(\mathrm{V}_{1 / 2}\right.$ act $)$ for $\mathrm{Na}_{\mathrm{v}} 1.1, \mathrm{Na}_{\mathrm{v}} 1.2$, and $\mathrm{Na}_{\mathrm{v}} 1.6$ for the control or isoflurane $(0.48 \mathrm{mM})$. Data are expressed as means \pm S.D. n.s., not significant by paired $t$ test $(P>0.05)$. 
A
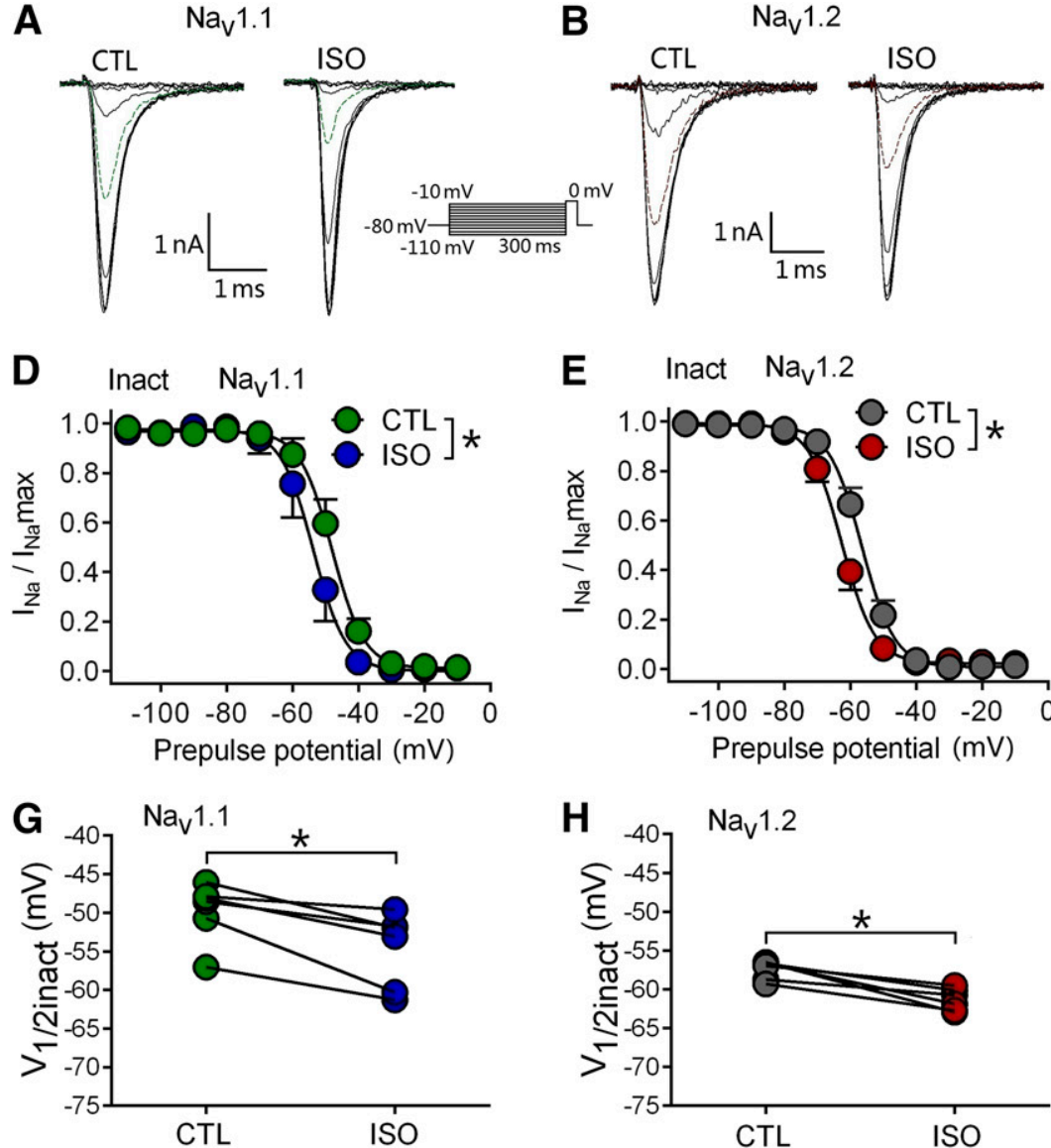

E Inact $\mathrm{Na}_{\mathrm{V}} 1.2$

$\mathrm{H}$

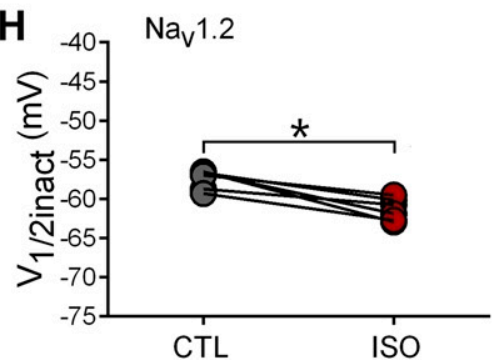

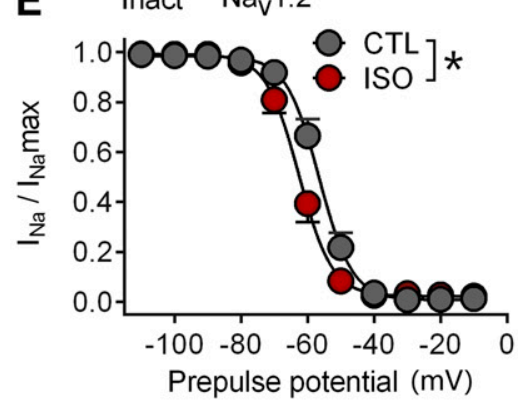

C
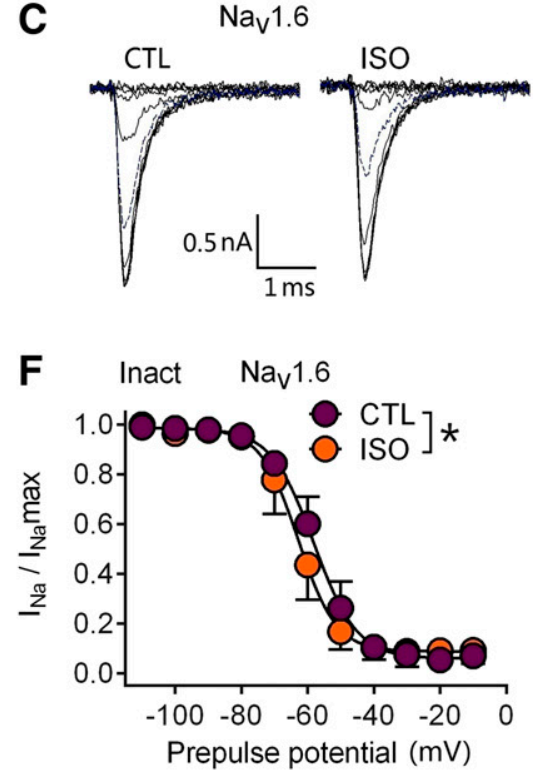

I

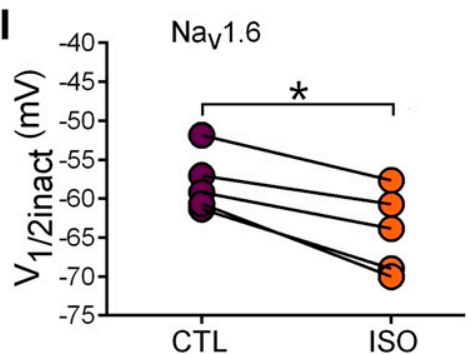

Fig. 2. Effects of isoflurane on steady-state fast inactivation of neuronal $\mathrm{Na}_{\mathrm{v}}$ subtypes. Isoflurane $(0.48 \mathrm{mM} ; 1.6 \mathrm{MAC})$ shifted the voltage of half-maximal inactivation $\left(\mathrm{V}_{1 / 2 \text { inact }}\right)$ in the hyperpolarizing direction for all three isoforms $\left(n=6\right.$ for $\mathrm{Na}_{\mathrm{v}} 1.1$ and $\mathrm{Na}_{\mathrm{v}} 1.2 ; n=5$ for $\mathrm{Na}_{\mathrm{v}} 1.6 ; P<0.05$ by twotailed, paired $t$ test). Steady-state inactivation was determined by eliciting currents at $0 \mathrm{mV}$ after a 300 -millisecond prepulse to voltages of -110 to $-10 \mathrm{mV}$ in $10-\mathrm{mV}$ steps (see inset). (A-C) Representative families of current traces in the absence (CTL) or presence of isoflurane (ISO) for Na 1.1 , $\mathrm{Na}_{\mathrm{v}} 1.2$, and $\mathrm{Na}_{\mathrm{v}} 1.6$. (D-F) Isoflurane shifted the voltage dependence of inactivation of $\mathrm{Na}_{\mathrm{v}} 1.1, \mathrm{Na}_{\mathrm{v}} 1.2$, and $\mathrm{Na}_{\mathrm{v}} 1.6$ in the hyperpolarized direction. Data are expressed as means \pm S.D. (G-I) Effects of isoflurane on the voltage of half-maximal inactivation $\left(\mathrm{V}_{1 / 2 \text { inact }}\right) . P<0.05$ by two-tailed, paired $t$ test.

$\mathrm{Na}_{\mathrm{v}}$ 1.6-mediated $\mathrm{Na}^{+}$currents in a model neuron based on the experimentally derived gating properties of each channel (Fig. 7, A-C). Simulated voltage-dependent activation and inactivation values of $\mathrm{Na}_{\mathrm{v}} 1.1, \mathrm{Na}_{\mathrm{v}} 1.2$, and $\mathrm{Na}_{\mathrm{v}} 1.6$ were similar to those obtained experimentally by patch-clamp electrophysiological recordings (Fig. 7, D-F). Values of $\mathrm{V}_{1 / 2 \text { act }}$ for $\mathrm{Na}_{\mathrm{v}} 1.1$, $\mathrm{Na}_{\mathrm{v}} 1.2$, and $\mathrm{Na}_{\mathrm{v}} 1.6$ were all $-15 \mathrm{mV}$, and values of $\mathrm{V}_{1 / 2 \text { inact }}$ for $\mathrm{Na}_{\mathrm{v}} 1.1, \mathrm{Na}_{\mathrm{v}} 1.2$, and $\mathrm{Na}_{\mathrm{v}} 1.6$ were $-50,-58$, and $-58 \mathrm{mV}$, respectively.

We also performed simulations to determine the temperature dependence of isoflurane effects on macroscopic $\mathrm{Na}_{\mathrm{v}}$ gating properties. After temperature correction to $37^{\circ} \mathrm{C}$, values of $\mathrm{V}_{1 / 2 \text { act }}$ for $\mathrm{Na}_{\mathrm{v}} 1.1, \mathrm{Na}_{\mathrm{v}} 1.2$, and $\mathrm{Na}_{\mathrm{v}} 1.6$ were all $-23 \mathrm{mV}$, and values of $\mathrm{V}_{1 / 2 \text { inact }}$ for $\mathrm{Na}_{\mathrm{v}} 1.1, \mathrm{Na}_{\mathrm{v}} 1.2$, and $\mathrm{Na}_{\mathrm{v}} 1.6$ were $-60,-68$, and $-69 \mathrm{mV}$, respectively (Fig. 7, G-I). At a temperature of $24^{\circ} \mathrm{C}$, isoflurane $(0.48 \mathrm{mM} ; 1.6 \mathrm{MAC})$ shifted the inactivation curves of $\mathrm{Na}_{\mathrm{v}} 1.1, \mathrm{Na}_{\mathrm{v}} 1.2$, and $\mathrm{Na}_{\mathrm{v}} 1.6$ in the hyperpolarized direction to $\mathrm{V}_{1 / 2 \text { inact }}$ values of $-55,-61$, and $-64 \mathrm{mV}$, respectively, with no effect on $\mathrm{V}_{1 / 2 \text { act }}$ (Fig. 7 , G-I). At a temperature of $37^{\circ} \mathrm{C}$, isoflurane ( 1.6 MAC) shifted the inactivation curves of $\mathrm{Na}_{\mathrm{v}} 1.1, \mathrm{Na}_{\mathrm{v}} 1.2$, and $\mathrm{Na}_{\mathrm{v}} 1.6$ in the hyperpolarized direction to $\mathrm{V}_{1 / 2 \text { inact }}$ values of $-65,-72$, and $-75 \mathrm{mV}$, respectively, with no effect on $\mathrm{V}_{1 / 2 \text { act }}$ (Fig. $7, \mathrm{G}-\mathrm{I}$ ).

Inhibition by isoflurane of $\mathrm{Na}_{\mathrm{v}} 1.1, \mathrm{Na}_{\mathrm{v}} 1.2$, and $\mathrm{Na}_{\mathrm{v}} 1.6$ from a holding potential of $-70 \mathrm{mV}$ was used for simulation of single APs at $37^{\circ} \mathrm{C}$. For an AP evoked by a current stimulus of $0.15 \mathrm{nA}$ (Fig. 8A), the simulated AP half-width was greater for $\mathrm{Na}_{\mathrm{v}} 1.2$ (1.3 milliseconds) than for $\mathrm{Na}_{\mathrm{v}} 1.6$ (0.7 milliseconds) or $\mathrm{Na}_{\mathrm{v}} 1.1$ (0.8 milliseconds). Isoflurane inhibited AP initiation mediated by $\mathrm{Na}_{\mathrm{v}} 1.2$ or $\mathrm{Na}_{\mathrm{v}} 1.6$, whereas APs mediated by $\mathrm{Na}_{\mathrm{v}} 1.1$ were minimally affected (Fig. 8B). When AP trains were evoked with a longer and larger-amplitude depolarizing stimulus (250-millisecond current injection at $0.5 \mathrm{nA}$, Fig. 8C), the simulated AP frequency was higher for $\mathrm{Na}_{\mathrm{v}} 1.6(92 \mathrm{~Hz})$ than for $\mathrm{Na}_{\mathrm{v}} 1.1(84 \mathrm{~Hz})$ or $\mathrm{Na}_{\mathrm{v}} 1.2(88 \mathrm{~Hz})$. Isoflurane reduced $\mathrm{AP}$ frequency to $80 \mathrm{~Hz}(-5.0 \%), 72 \mathrm{~Hz}(-18.2 \%)$, or $71 \mathrm{~Hz}(-22.8 \%)$ for $\mathrm{Na}_{\mathrm{v}} 1.1, \mathrm{Na}_{\mathrm{v}} 1.2$, and $\mathrm{Na}_{\mathrm{v}} 1.6$, respectively (Fig. 8D). Simulation of EPSCs was based on the effects of isoflurane on AP amplitude and firing frequency as a prediction of effects on synaptic transmission. Isoflurane depressed single AP amplitude from 131, 132, and $132 \mathrm{mV}$ to 128, 66, and $61 \mathrm{mV}$ for $\mathrm{Na}_{\mathrm{v}} 1.1, \mathrm{Na}_{\mathrm{v}} 1.2$, and $\mathrm{Na}_{\mathrm{v}} 1.6$, respectively (Fig. 8B). The depression by isoflurane of EPSCs was significant for $\mathrm{Na}_{\mathrm{v}}$ 1.2- and $\mathrm{Na}_{\mathrm{v}}$ 1.6-mediated transmission but minimal for $\mathrm{Na}_{\mathrm{v}}$ 1.1-mediated transmission (Fig. 8F).

\section{Discussion}

In a combined electrophysiological and simulation study, we determined the major neuronal $\mathrm{Na}_{\mathrm{v}}$ subtype-specific effects of 
A

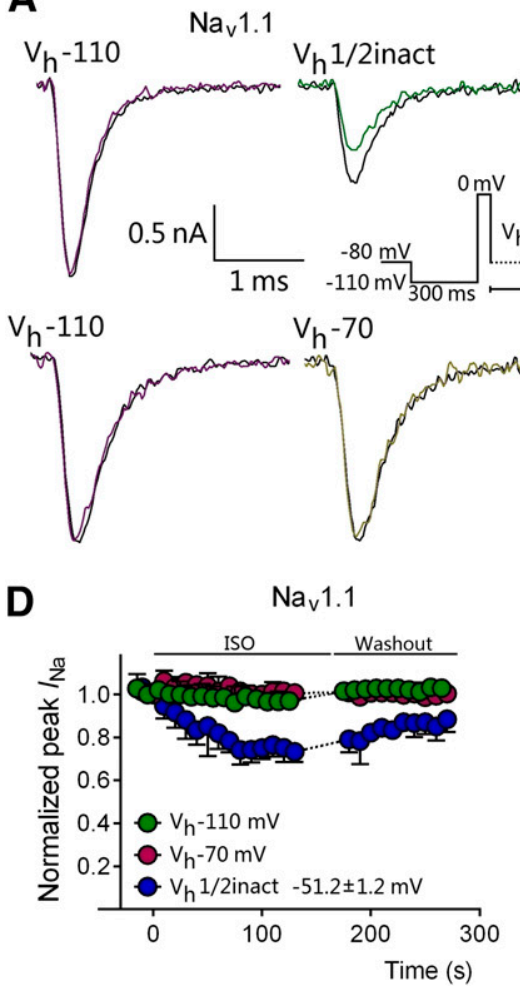

B

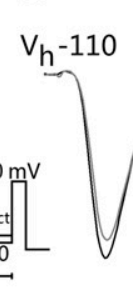

$\mathrm{Na}_{\mathrm{v}} 1.2$

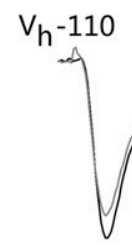

E

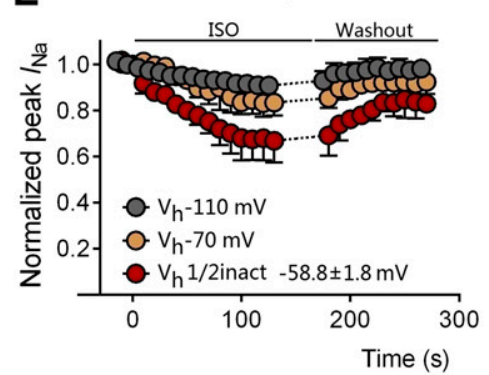

C
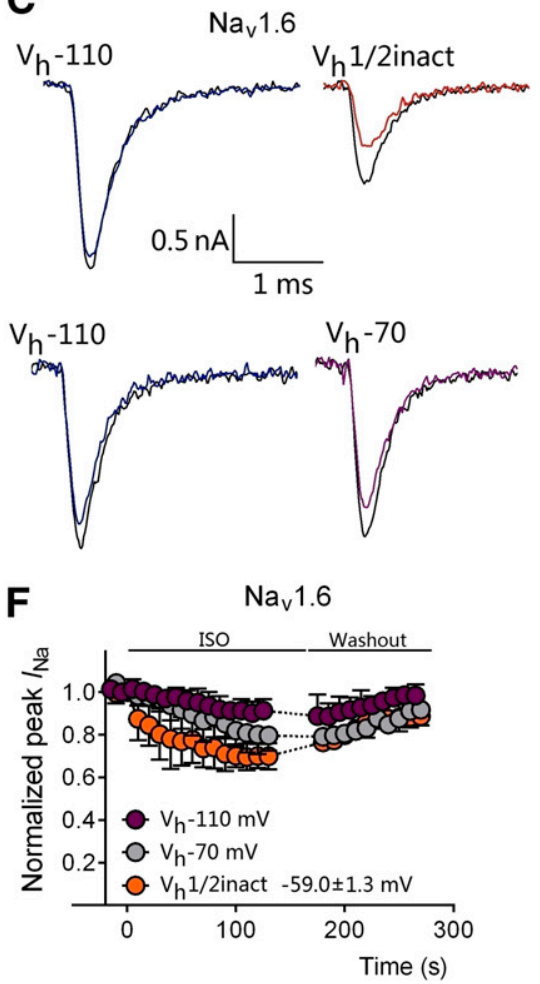

Fig. 3. Inhibition of peak $\mathrm{Na}^{+}$current $\left(I_{\mathrm{Na}}\right)$ during wash-in and washout of isoflurane. Effect of $0.49 \mathrm{mM}(1.6 \mathrm{MAC})$ isoflurane with an alternating pulse protocol to elicit peak $I_{\mathrm{Na}}$ by a prepulse to $-110 \mathrm{mV},-70 \mathrm{mV}$, or $\mathrm{V}_{1 / 2 \text { inact }}$ (voltage of half-maximal inactivation) $(n=6)$. $\mathrm{V}_{1 / 2 \text { inact }}$ was determined for each individual cell prior to control recording. (A) Representative traces for $\mathrm{Na}_{\mathrm{v}} 1.1$ for the control (black traces) or isoflurane (ISO; colored traces). No inhibition was observed for $\mathrm{Na}_{\mathrm{v}} 1.1$ from a holding potential $\left(\mathrm{V}_{\mathrm{h}}\right)$ of -110 or $-70 \mathrm{mV}$. (B) Representative traces for $\mathrm{Na}_{\mathrm{v}} 1.2$ for the control or isoflurane. (C) Representative traces for $\mathrm{Na}_{\mathrm{v}} 1.6$ for the control or isoflurane. (D-F) Inhibition by isoflurane of $\mathrm{Na}_{\mathrm{v}}$ subtypes. Data are expressed as means \pm S.D.

isoflurane on channel gating properties, AP firing, and synaptic transmission. Although voltage-dependent activation of $\mathrm{Na}_{\mathrm{v}}$ was similar between the three major neuronal subtypes, their voltage dependence of inactivation differed, with that of $\mathrm{Na}_{\mathrm{v}} 1.1$ being more positive compared with $\mathrm{Na}_{\mathrm{v}} 1.2$ and $\mathrm{Na}_{\mathrm{v}}$ 1.6. This is consistent with previous reports that the $\mathrm{V}_{1 / 2 \text { inact }}$ of $\mathrm{Na}_{\mathrm{v}} 1.1$ is more positive than that of $\mathrm{Na}_{\mathrm{v}} 1.6$ when heterologously expressed in human embryonic kidney cells (Patel et al., 2015; Fruscione et al., 2018). These differences in inactivation gating lead to greater isoflurane-induced fast inactivation and inhibition of peak $I_{\mathrm{Na}}$ for $\mathrm{Na}_{\mathrm{v}} 1.2$ and $\mathrm{Na}_{\mathrm{v}} 1.6$ compared with $\mathrm{Na}_{\mathrm{v}} 1.1$ at a physiologic holding potential. The greater anesthetic sensitivity of $\mathrm{Na}_{\mathrm{v}} 1.2$ and $\mathrm{Na}_{\mathrm{v}} 1.6$ provides a plausible mechanism for brain region- and neurotransmitterselective effects of isoflurane on synaptic transmission due to differential expression of $\mathrm{Na}_{\mathrm{v}}$ subtypes between neuron subtypes and within neuronal compartments (Wood and Baker, 2001; Johnson et al., 2017).

All clinically used volatile anesthetics inhibit the major $\mathrm{Na}_{\mathrm{v}}$ subtypes, including brain $\mathrm{Na}_{\mathrm{v}} 1.2$, skeletal muscle $\mathrm{Na}_{\mathrm{v}} 1.4$, and cardiac $\mathrm{Na}_{\mathrm{v}} 1.5$ (OuYang and Hemmings, 2007). Inhibition by volatile anesthetics of $\mathrm{Na}_{\mathrm{v}} 1.5$ contributes to their modulation of electrophysiological properties including APs in cardiomyocytes (Eskinder et al., 1993; Raatikainen et al., 1998). Of the nine identified $\mathrm{Na}_{\mathrm{v}}$ subtypes $\left(\mathrm{Na}_{\mathrm{v}} 1.1-\mathrm{Na}_{\mathrm{v}} 1.9\right), \mathrm{Na}_{\mathrm{v}} 1.1$, $\mathrm{Na}_{\mathrm{v}} 1.2$, and $\mathrm{Na}_{\mathrm{v}} 1.6$ are highly expressed in the CNS (Black and Waxman, 1996; Wood and Baker, 2001). Advantages of expressing neuronal $\mathrm{Na}_{\mathrm{v}}$ subtypes in the ND7/23 neuroblastoma/dorsal root ganglion hybridoma cell line include robust expression in the presence of critical auxiliary subunits and other neuronal signaling pathways, minimal space-clamp issues compared with mature isolated neurons facilitating reliable voltage-control during electrophysiological recordings (Herold et al., 2009), and expression and function in a uniform neuronal background minimizing effects of neuronal subtype heterogeneity (John et al., 2004; Rogers et al., 2016).

Even small reductions in $I_{\mathrm{Na}}$ have large electrophysiological consequences due to nonlinear coupling (Fujiwara et al., 1988; Goldin, 2001; Engel and Jonas, 2005). Small differences in

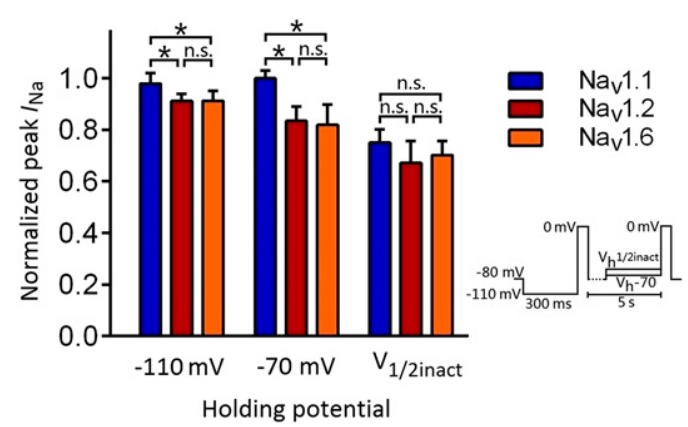

Fig. 4. Inhibition of peak $\mathrm{Na}^{+}$current $\left(I_{\mathrm{Na}}\right)$ by isoflurane. From a holding potential $\left(\mathrm{V}_{\mathrm{h}}\right)$ of $-110 \mathrm{mV}$, isoflurane $(0.49 \pm 0.03 \mathrm{mM} ; 1.6 \mathrm{MAC})$ inhibited peak $I_{\mathrm{Na}}$ of $\mathrm{Na}_{\mathrm{v}} 1.2$ and $\mathrm{Na}_{\mathrm{v}} 1.6$, but not of $\mathrm{Na}_{\mathrm{v}} 1.1$. From a holding potential of $-70 \mathrm{mV}$, isoflurane inhibited peak $I_{\mathrm{Na}}$ of $\mathrm{Na}_{\mathrm{v}} 1.2$ and $\mathrm{Na}_{\mathrm{v}} 1.6$, but not of $\mathrm{Na}_{\mathrm{v}}$ 1.1. From a holding potential of $\mathrm{V}_{1 / 2 \text { inact }}$ (voltage of half-maximal inactivation), isoflurane inhibited peak $I_{\mathrm{Na}}$ of $\mathrm{Na}_{\mathrm{v}} 1.1, \mathrm{Na}_{\mathrm{v}} 1.2$, and $\mathrm{Na}_{\mathrm{v}} 1.6$ with similar efficacy $(P>0.05$ by ANOVA). Data are expressed as means \pm S.D. $(n=5$ to 6$)$. ${ }^{*} P<0.05$ vs. $\mathrm{Na}_{\mathrm{v}} 1.1$. n.s., not significant $(P>0.05)$. 


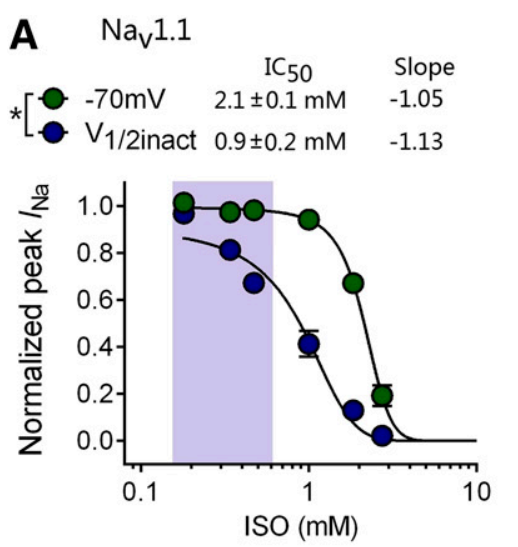

D

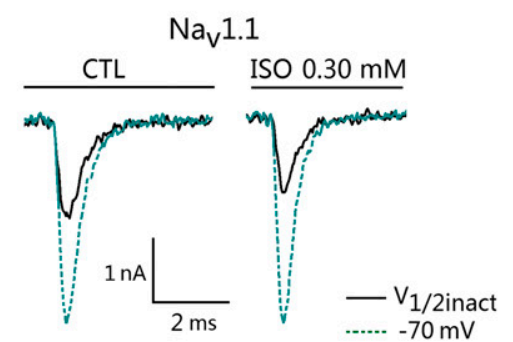

E
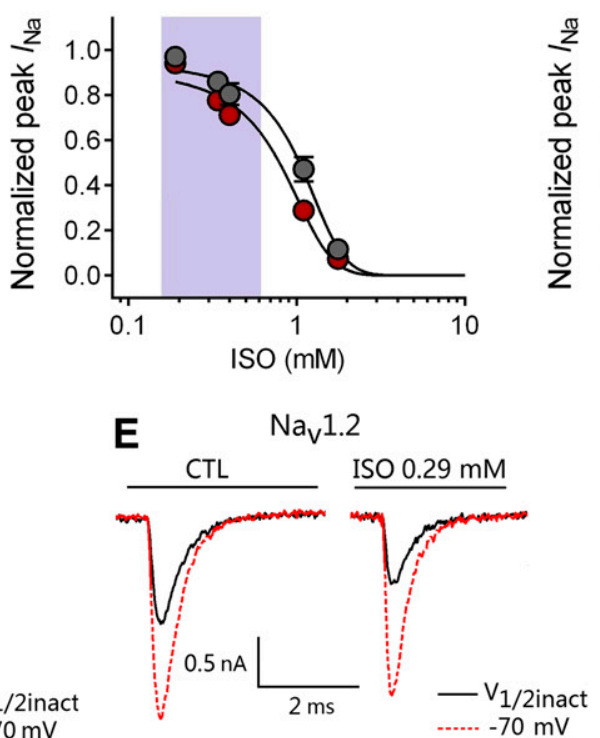

B $\quad \mathrm{Na}_{\mathrm{v}} 1.2$

1.31
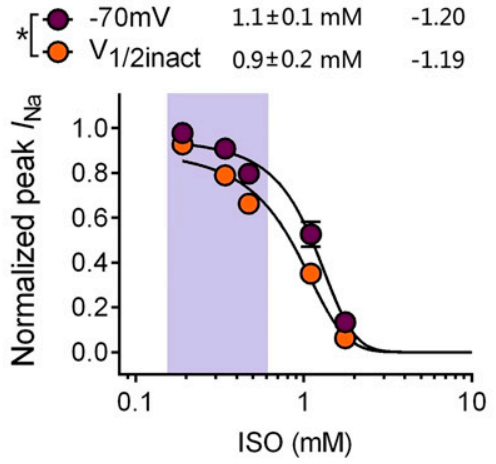

F $\quad \mathrm{Na}_{\mathrm{v}} 1.6$

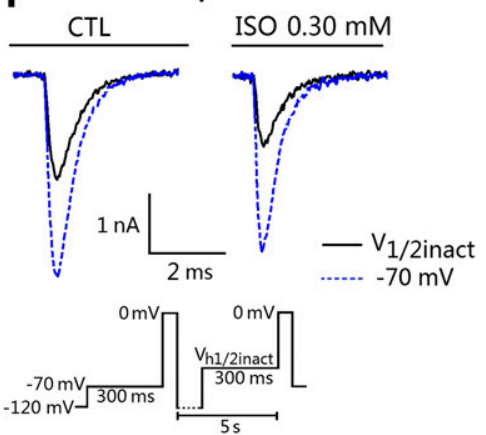

G

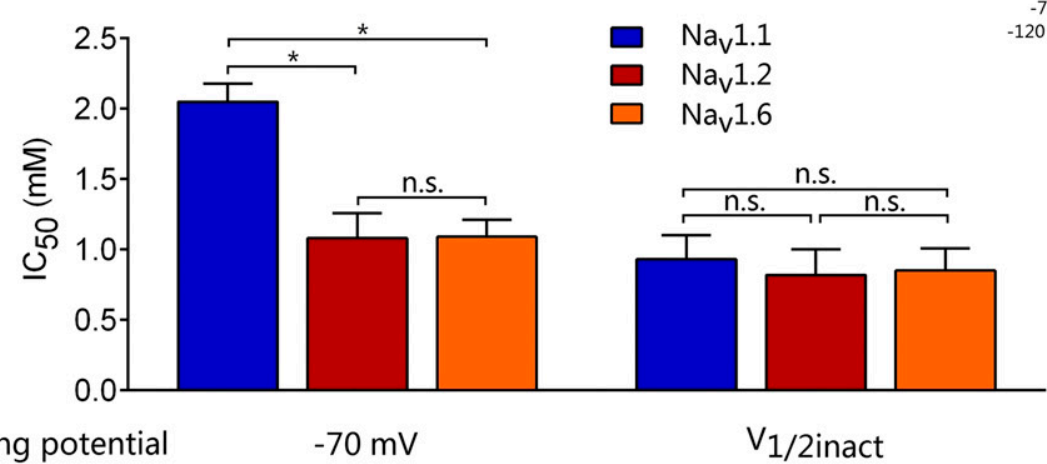

Holding potential $\quad-70 \mathrm{mV} \quad \mathrm{V}_{1 / 2 \text { inact }}$

Fig. 5. Concentration-dependent effects of isoflurane on $\mathrm{Na}_{\mathrm{v}}$ subtypes. $\mathrm{IC}_{50}$ values for isoflurane inhibition of $\mathrm{Na}_{\mathrm{v}}$ subtypes from holding potentials of $-70 \mathrm{mV}$ or $\mathrm{V}_{1 / 2 i n a c t}$. (A-C) Data for concentration-dependent inhibition of peak $I_{\mathrm{Na}}$ by isoflurane were well fitted to a Hill equation with significant voltage-dependent inhibition $(P<0.05$ by paired $t$ test). The shaded area indicates the clinical concentration range of isoflurane $(0.15-0.6 \mathrm{mM} ; 0.5-2.0$ MAC). (D-F) Representative $\mathrm{Na}^{+}$current traces for the control or isoflurane (ISO). (G) From a holding potential of $-70 \mathrm{mV}, \mathrm{Na}_{\mathrm{v}} 1.2(n=20)$ and $\mathrm{Na}_{\mathrm{v}} 1.6$ $(n=17)$ were more sensitive to isoflurane inhibition compared with $\mathrm{Na}_{\mathrm{v}} 1.1(n=19)$. From a holding potential of $\mathrm{V}_{1 / 2 \text { inact }}, \mathrm{IC}_{50}$ values were similar for all three $\mathrm{Na}_{\mathrm{v}}$ subtypes. ${ }^{*} P<0.05$ by ANOVA with post hoc Bonferroni correction. Data are expressed as means \pm S.D. $(n=3-5$ for each point). n.s., not significant $(P>0.05)$.

presynaptic $\mathrm{AP}$ shape can produce large changes in the timing and magnitude of presynaptic $\mathrm{Ca}^{2+}$ entry because the kinetics of $\mathrm{Ca}^{2+}$ channels are strongly voltage dependent (Clark et al., 1996; Clarke et al., 2016). Thus, AP-evoked $\mathrm{Ca}^{2+}$ entry can have a steep dependence on AP shape, which can translate into significant changes in $\mathrm{Ca}^{2+}$ entry and even more dramatic changes in transmitter release and postsynaptic currents (Bean, 2007). Volatile anesthetics inhibit $\mathrm{Na}_{\mathrm{v}}$ and APs at clinically relevant concentrations (Westphalen and Hemmings, 2003b, 2006; Wu et al., 2004; Herold and Hemmings, 2012). Based on our findings, the simulated AP half-width is greater for $\mathrm{Na}_{\mathrm{v}} 1.2$ and $\mathrm{Na}_{\mathrm{v}} 1.1$ than for $\mathrm{Na}_{\mathrm{v}} 1.6$, whereas the AP train frequency is higher for $\mathrm{Na}_{\mathrm{v}} 1.6$ than for $\mathrm{Na}_{\mathrm{v}} 1.1$ and $\mathrm{Na}_{\mathrm{v}} 1.2$, consistent with $\mathrm{Na}_{\mathrm{v}} 1.6$ as an important contributor to fast repetitive firing (Khaliq et al., 2003; Brackenbury et al., 2010). Our findings provide a mechanistic basis for previous observations that isoflurane inhibits neurotransmitter release and spontaneous firing patterns of hippocampal neurons in an activity-dependent manner (Fujiwara et al., 1988; Goldin, 2001; Wu et al., 2004; Purtell et al., 2015).

Isoflurane suppressed peak $\mathrm{Na}^{+}$current, produced a hyperpolarizing shift in the voltage dependence of fast inactivation, and slowed recovery from fast inactivation of brain $\mathrm{Na}_{\mathrm{v}}$ subtypes at a physiologically relevant membrane potential. These effects might involve more than one site of interaction of isoflurane with $\mathrm{Na}_{\mathrm{v}}$ since volatile anesthetics appear to have multiple sites of interaction with voltage-gated ion channels including $\mathrm{Na}_{\mathrm{v}}$ (Raju et al., 2013; Spurny et al., 2013; Sand et al., 2017). At a hyperpolarized holding potential, none of the $\mathrm{Na}_{\mathrm{v}}$ subtypes were inhibited by isoflurane, consistent with a low affinity of isoflurane for the resting state of $\mathrm{Na}_{\mathrm{v}}$. From hyperpolarized or physiologic holding potentials, isoflurane did not inhibit $\mathrm{Na}_{\mathrm{v}} 1.1$-mediated peak $I_{\mathrm{Na}}$ but did inhibit $\mathrm{Na}_{\mathrm{v}} 1.2$ and $\mathrm{Na}_{\mathrm{v}} 1.6$ at a physiologic membrane potential. 
A
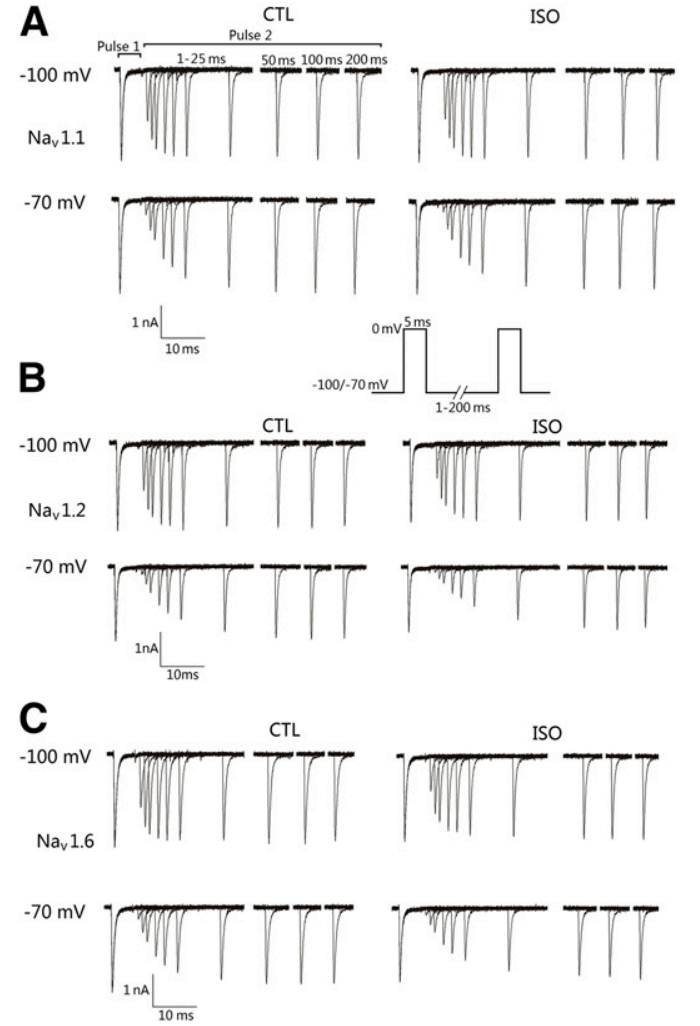

D

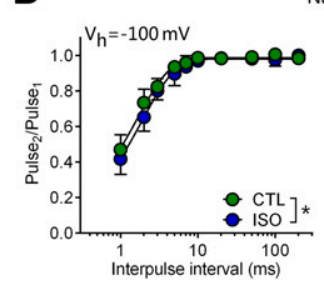

$\mathrm{Na}_{\mathrm{v}} 1.1$

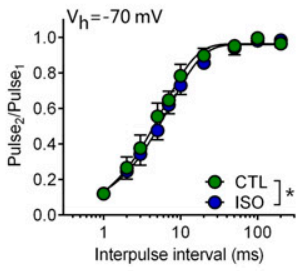

E

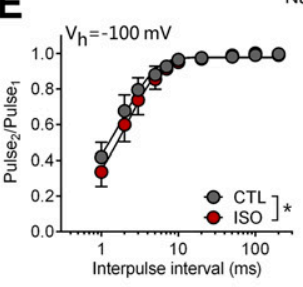

$\mathrm{Na}_{\mathrm{v}} 1.2$

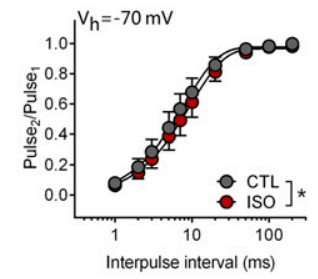

$\mathbf{F}$
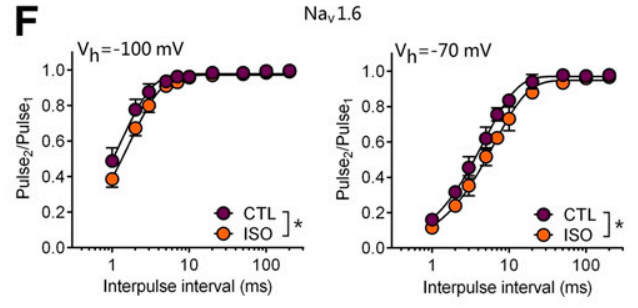

G

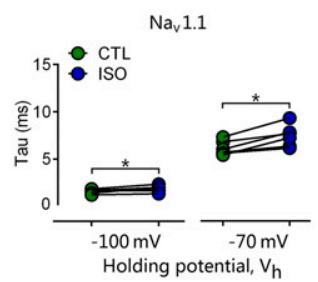

H

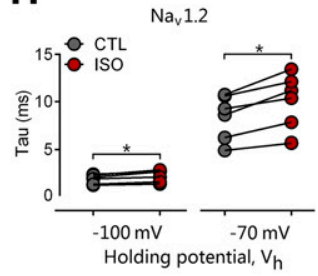

I

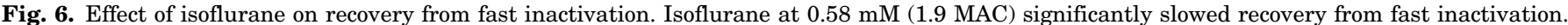

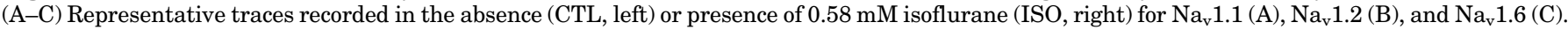

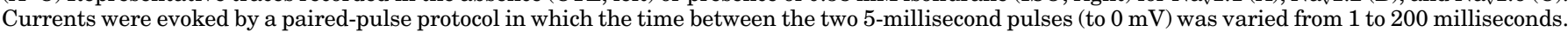

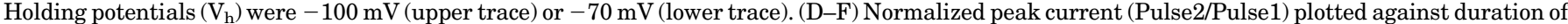

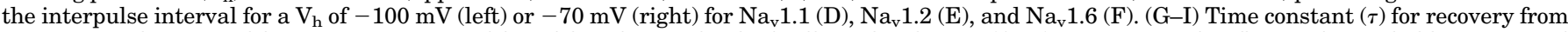

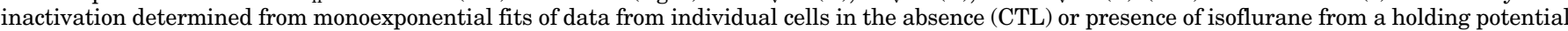
of $-100 \mathrm{mV}(n=6)$ or $-70 \mathrm{mV}(n=6)$. Data are presented as means \pm S.D. $* P<0.05$ vs. CTL by two-tailed, paired $t$ test.

Further studies are required to determine whether differences in anesthetic binding sites contribute to this subtype-selective sensitivity to isoflurane.

All neuronal $\mathrm{Na}_{\mathrm{v}}$ subtypes were inhibited to a similar degree from holding potentials near their $\mathrm{V}_{1 / 2 \text { inact }}$, a potential at which $50 \%$ of channels are closed or inactivated, indicating that isoflurane has similar quantitative effects on $\mathrm{Na}_{\mathrm{v}} 1.1-$, $\mathrm{Na}_{\mathrm{v}} 1.2-$, and $\mathrm{Na}_{\mathrm{v}} 1.6-$ mediated currents when currents are measured at equivalent states of inactivation. Since the $V_{1 / 2 \text { inact }}$ is more positive for $\mathrm{Na}_{\mathrm{v}} 1.1$ than for $\mathrm{Na}_{\mathrm{v}} 1.2$ or $\mathrm{Na}_{\mathrm{v}} 1.6$, isoflurane showed greater inhibition of $\mathrm{Na}_{\mathrm{v}} 1.2$ and $\mathrm{Na}_{\mathrm{v}} 1.6$ compared with $\mathrm{Na}_{\mathrm{v}} 1.1$ at a holding potential of $-70 \mathrm{mV}$, supporting preferential interaction with inactivated channels. At this holding potential, $\mathrm{Na}_{\mathrm{v}} 1.2$ and $\mathrm{Na}_{\mathrm{v}} 1.6$ have a higher proportion of channels in the inactivated state compared with $\mathrm{Na}_{\mathrm{v}} 1.1$, leading to preferential inhibition of $\mathrm{Na}_{\mathrm{v}} 1.2$ and $\mathrm{Na}_{\mathrm{v}} 1.6$ by isoflurane. Thus, the differential sensitivity of neuronal $\mathrm{Na}_{\mathrm{v}}$ subtypes to isoflurane can be explained by differences in voltage-dependent gating rather than by subtype-specific differences in drug sensitivity per se. These findings suggest conserved sites of interaction between isoflurane and the major neuronal $\mathrm{Na}_{\mathrm{v}}$ subtypes, which are highly homologous (Black and Waxman, 1996; Wood and Baker, 2001). Identification of their pharmacologically relevant binding site(s) should clarify whether volatile anesthetics interact with structurally homologous sites in $\mathrm{Na}_{\mathrm{v}}$ (Sand et al., 2017).

Neuronal excitability and synaptic transmission show physiologic and pharmacological differences between brain regions and between neurons of different neurotransmitter phenotype (Pinheiro and Mulle, 2008; Spruston, 2008). Some of this heterogeneity could derive from differences in relative expression of various neuronal $\mathrm{Na}_{\mathrm{v}}$ subtypes having distinct voltage-dependent gating properties, with physiologic and pharmacological implications (Lai and Jan, 2006; Ogiwara et al., 2007; Lorincz and Nusser, 2008b; Johnson et al., 2017). Specific $\mathrm{Na}_{\mathrm{v}}$ subtypes are selectively expressed on presynaptic and postsynaptic glutamatergic synapses in the hippocampus, consistent with subtype-specific roles in neurotransmitter release and synaptic plasticity (Johnson et al., 2017). Most excitatory neurons express a high density of $\mathrm{Na}_{\mathrm{v}} 1.6$ and $\mathrm{Na}_{\mathrm{v}} 1.2$ (Whitaker et al., 2000; Tian et al., 2014), whereas $\mathrm{Na}_{\mathrm{v}} 1.1$ is preferentially expressed in inhibitory GABAergic interneurons (Ogiwara et al., 2007; Lorincz and Nusser, 2008a).

Neurotransmitter phenotype-specific expression and sensitivity to isoflurane inhibition of neuronal $\mathrm{Na}_{\mathrm{v}}$ subtypes could underlie the greater isoflurane sensitivity of $\mathrm{Na}_{\mathrm{v}}$-dependent release of glutamate compared with GABA (Westphalen and Hemmings, 2006; Baumgart et al., 2015; Purtell et al., 2015). Further studies of the relationship between the functionally selective effects of isoflurane on $\mathrm{Na}_{\mathrm{v}}$ subtypes and various pharmacological endpoints might provide leads for the development of more selective and potentially safer general anesthetic agents that selectively target specific $\mathrm{Na}_{\mathrm{v}}$ subtypes. The function and gating kinetics of neuronal $\mathrm{Na}_{\mathrm{v}}$ are also modulated by phosphorylation, calmodulin binding (Cantrell 
A

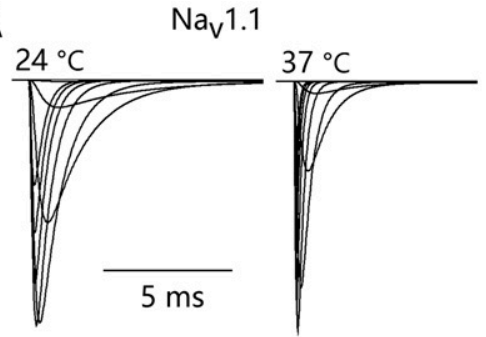

D
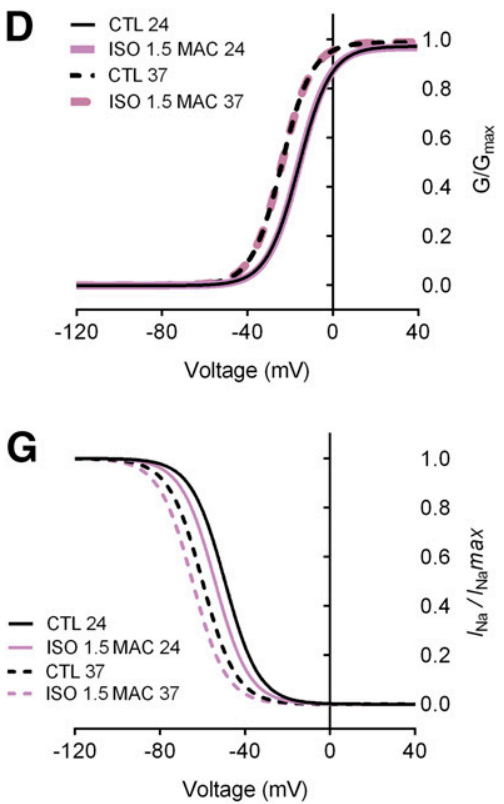

B

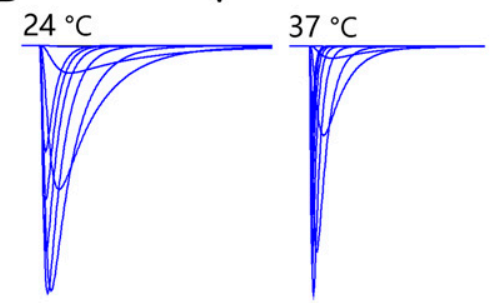

E
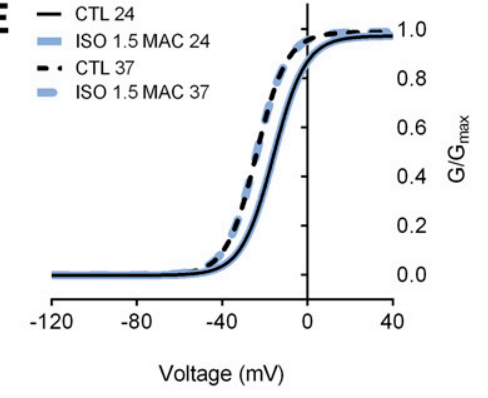

H

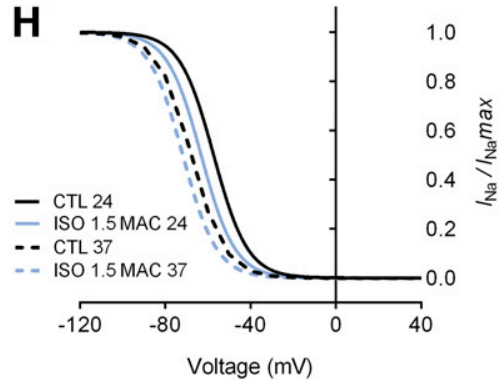

C

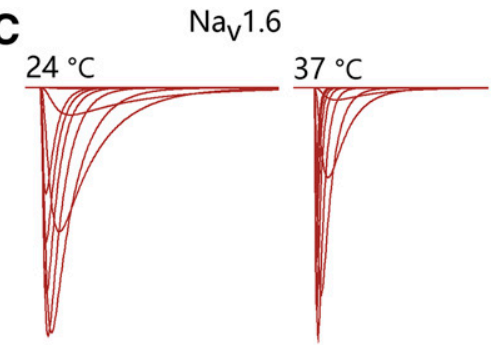

$\mathbf{F}$

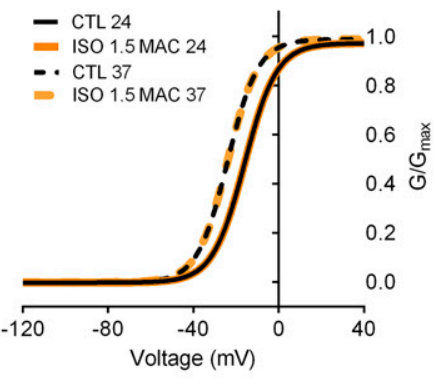

$1+1.0$

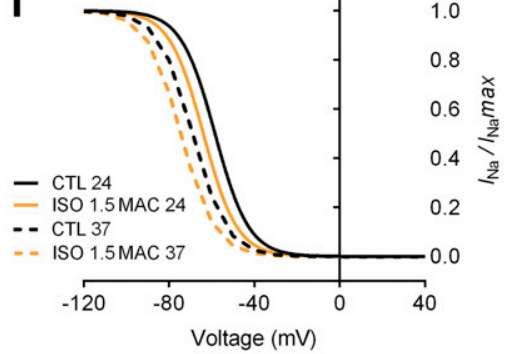

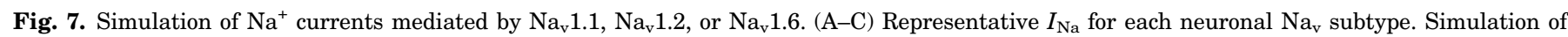

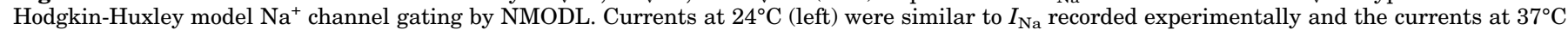

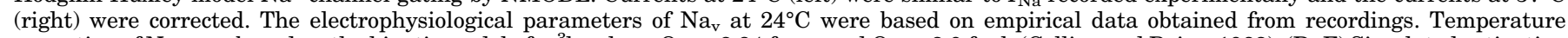

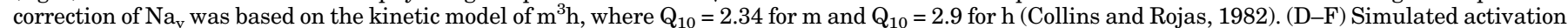

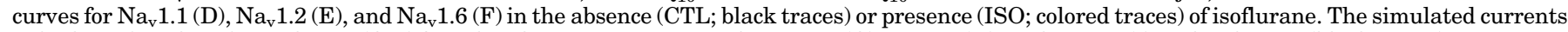

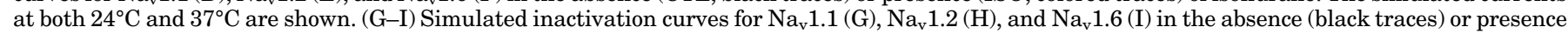
(colored traces) of isoflurane. The simulated currents at both $24^{\circ} \mathrm{C}$ and $37^{\circ} \mathrm{C}$ are shown. CTL, control; ISO, isoflurane.

and Catterall, 2001; Pitt and Lee, 2016; Yan et al., 2017), and auxiliary subunits (Wimmer et al., 2015), which could further modulate $\mathrm{Na}_{\mathrm{v}}$ sensitivity to general anesthetics.

This study has certain limitations. We used well characterized $\mathrm{Na}_{\mathrm{v}}$ subtypes from different mammalian species (human, rat, and mouse), since their amino acid sequences are $>98 \%$ conserved; species-specific differences in $\mathrm{Na}_{\mathrm{v}}$ properties and anesthetic sensitivity are possible but unlikely and have not been reported (Whitaker et al., 2001; Lewis and Raman, 2011; Carrasco et al., 2017). The single point mutations to produce TTX resistance introduce a difference from wild-type channels with possible unanticipated effects on drug binding. However, these mutations are in the extracellular toxin binding domain and have not been shown to affect gating properties, channel kinetics, or anesthetic sensitivity compared with native hippocampal neuron channels (Herzog et al., 2003; Leffler et al., 2005; Purtell et al., 2015; Carrasco et al., 2017).

Although our simulation studies support our conclusions, the functional predictions have not been validated in intact neurons. Recordings of native $I_{\mathrm{Na}}$ from intact neurons are not an ideal model for comparing $\mathrm{Na}_{\mathrm{v}}$ subtypes, since it is impossible to isolate the individual subtype and selectively expressing TTX-resistant subtypes in cultured neurons is complicated by the heterogeneity of neuron types. All electrophysiological recordings were performed at room temperature (23 to $24^{\circ} \mathrm{C}$ ), as are most electrophysiological studies because of recording stability and reliability. Although we used a simulated model to correct the temperature to $37^{\circ} \mathrm{C}$, the effects of isoflurane at $37^{\circ} \mathrm{C}$ were not measured directly, and whether isoflurane would more potently inhibit $\mathrm{Na}_{\mathrm{v}}$ at $37^{\circ} \mathrm{C}$ is therefore unclear. Since the voltage dependence of $\mathrm{Na}_{\mathrm{v}}$ inactivation was hyperpolarized at the physiologic temperature of $37^{\circ} \mathrm{C}$, inhibition by isoflurane of $\mathrm{Na}^{+}$currents would be enhanced compared with $24^{\circ} \mathrm{C}$, with perhaps more marked effects on excitability and AP properties. Although all volatile anesthetics tested inhibit $\mathrm{Na}_{\mathrm{v}}$ (OuYang and Hemmings, 2007), we only tested isoflurane and cannot extrapolate these effects to other clinically used volatile anesthetics, and it is possible that agent-specific effects exist.

In conclusion, $\mathrm{Na}^{+}$currents mediated by the principal neuronal $\mathrm{Na}_{\mathrm{v}}$ subtypes $\mathrm{Na}_{\mathrm{v}} 1.1, \mathrm{Na}_{\mathrm{v}} 1.2$, and $\mathrm{Na}_{\mathrm{v}} 1.6$ exhibit different sensitivities to inhibition by isoflurane, leading to reduced inhibition of $\mathrm{Na}_{\mathrm{v}} 1.1$ compared with $\mathrm{Na}_{\mathrm{v}} 1.2$ and $\mathrm{Na}_{\mathrm{v}}$ 1.6. This differential sensitivity can be explained by fundamental differences in voltage-dependent gating properties 
A

$0.05 n A+C T L$

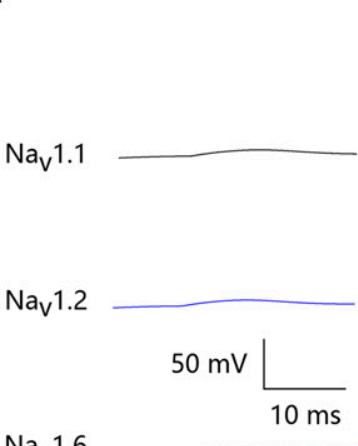

$\mathrm{Na}_{\mathrm{v}} 1.6$

C

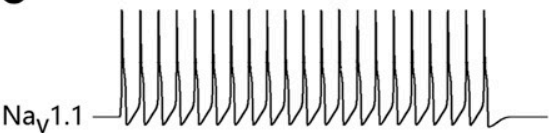

$0.5 \mathrm{nA}+\mathrm{CTL}$

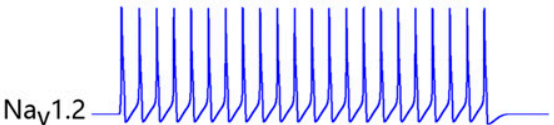

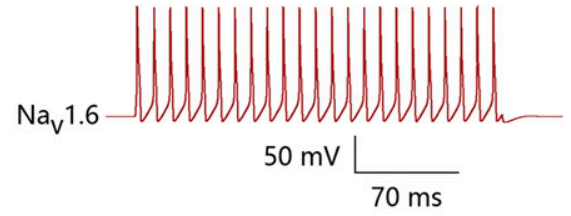

B

$0.15 \mathrm{nA}+\mathrm{ISO}$
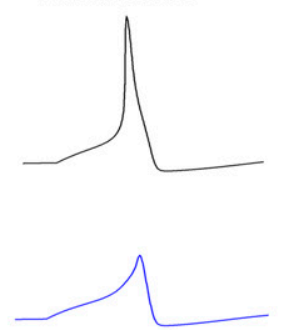
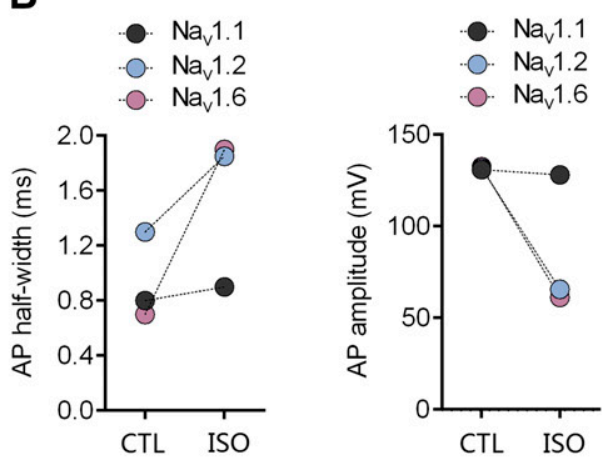

$0.5 \mathrm{nA}+\mathrm{ISO}$
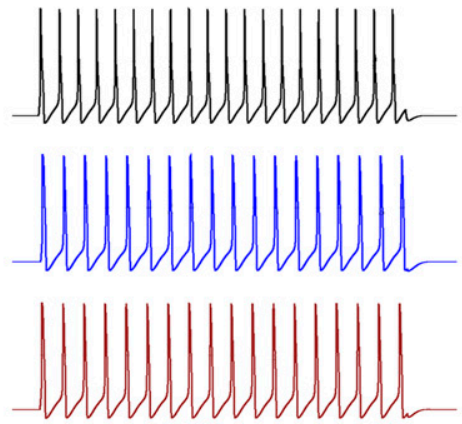

D
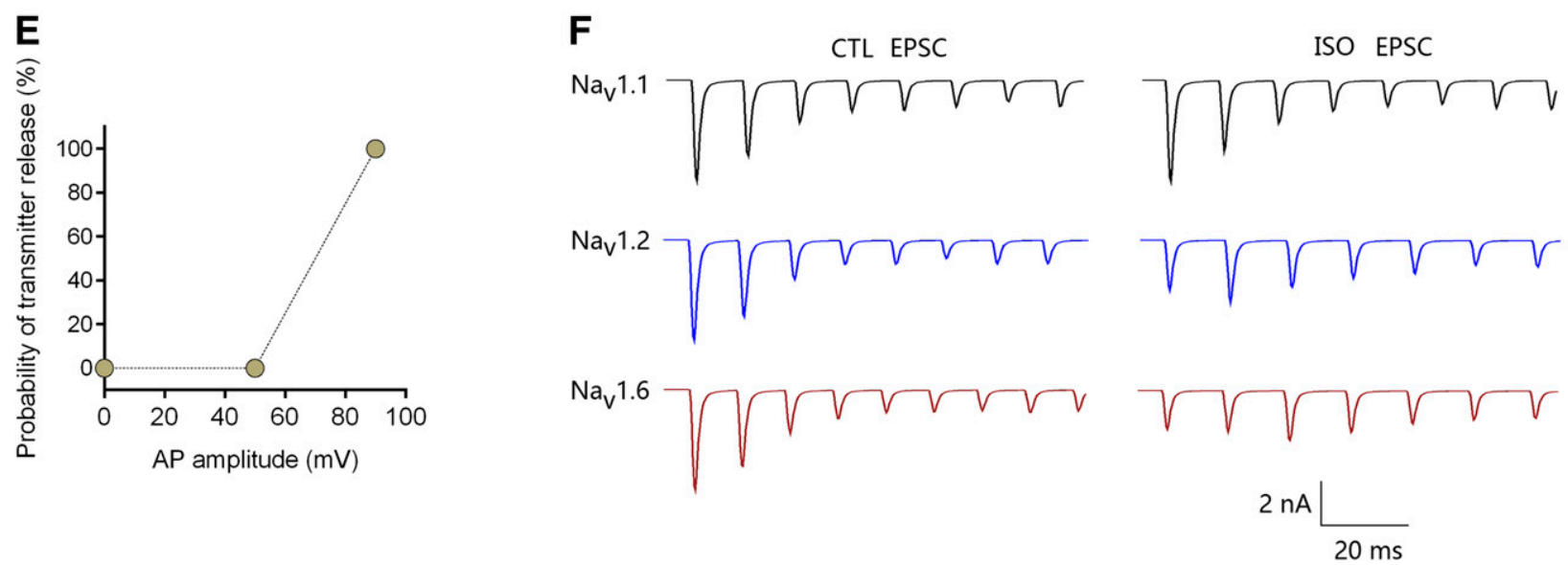

Fig. 8. Simulated effects of isoflurane on action potentials and synaptic transmission mediated by $\mathrm{Na}_{\mathrm{v}} 1.1, \mathrm{Na}_{\mathrm{v}} 1.2$, or $\mathrm{Na}_{\mathrm{v}} 1.6$. Channel gating kinetics were temperature corrected to $37^{\circ} \mathrm{C}$. (A) Effects of isoflurane (ISO) on single AP morphology evoked by $0.15 \mathrm{nA}$ for 10 milliseconds. (B) Effects of isoflurane on half-width and amplitude of single APs mediated by $\mathrm{Na}_{\mathrm{v}} 1.1, \mathrm{Na}_{\mathrm{v}} 1.2$, or $\mathrm{Na}_{\mathrm{v}} 1.6$. (C) Effects of isoflurane on AP trains evoked by a larger stimulus of $0.5 \mathrm{nA}$ for 250 milliseconds. (D) Effects of isoflurane on AP frequency mediated by $\mathrm{Na}_{\mathrm{v}} 1.1, \mathrm{Na}_{\mathrm{v}} 1.2$, or $\mathrm{Na}_{\mathrm{v}} 1.6$. (E) The relationship between AP amplitude and probability of transmitter release was modified from an established nerve terminal model (Graham and Redman, 1994). (F) Simulated effects of isoflurane on postsynaptic EPSCs mediated by $\mathrm{Na}_{\mathrm{v}} 1.1, \mathrm{Na}_{\mathrm{v}} 1.2$, or $\mathrm{Na}_{\mathrm{v}} 1.6$.

between channel subtypes. Thus, differences in the expression of specific $\mathrm{Na}_{\mathrm{v}}$ subtypes between brain regions, neurons, and synapses could underlie brain region- and neurotransmitterselective effects of isoflurane, and perhaps other volatile anesthetics, on CNS function.

\section{Authorship Contributions}

Participated in research design: Zhou, Herold, Hemmings.

Conducted experiments: Zhou, Johnson.

Contributed new reagents or analytic tools: Zhou, Herold.

Performed data analysis: Zhou, Herold, Hemmings.
Wrote or contributed to the writing of the manuscript: Zhou, Johnson, Herold, Hemmings.

\section{References}

Akemann W, Lundby A, Mutoh H, and Knöpfel T (2009) Effect of voltage sensitive fluorescent proteins on neuronal excitability. Biophys J 96:3959-3976.

Baumgart JP, Zhou ZY, Hara M, Cook DC, Hoppa MB, Ryan TA, and Hemmings HC Jr (2015) Isoflurane inhibits synaptic vesicle exocytosis through reduced $\mathrm{Ca} 2+$ influx, not Ca2+-exocytosis coupling. Proc Natl Acad Sci USA 112: 11959-11964.

Bean BP (2007) The action potential in mammalian central neurons. Nat Rev Neurosci 8:451-465.

Bezanilla F and Armstrong CM (1977) Inactivation of the sodium channel. I. Sodium current experiments. $J$ Gen Physiol 70:549-566. 
Black JA and Waxman SG (1996) Sodium channel expression: a dynamic process in neurons and non-neuronal cells. Dev Neurosci 18:139-152.

Brackenbury WJ, Calhoun JD, Chen C, Miyazaki H, Nukina N, Oyama F, Ranscht B, and Isom LL (2010) Functional reciprocity between Na + channel Nav1.6 and beta1 subunits in the coordinated regulation of excitability and neurite outgrowth. Proc Natl Acad Sci USA 107:2283-2288.

Cantrell AR and Catterall WA (2001) Neuromodulation of $\mathrm{Na}+$ channels: an unexpected form of cellular plasticity. Nat Rev Neurosci 2:397-407.

Carrasco DI, Vincent JA, and Cope TC (2017) Distribution of TTX-sensitive voltagegated sodium channels in primary sensory endings of mammalian muscle spindles. J Neurophysiol 117:1690-1701.

Catterall WA, Goldin AL, and Waxman SG (2005) International Union of Pharmacology. XLVII. Nomenclature and structure-function relationships of voltage-gated sodium channels. Pharmacol Rev 57:397-409.

Cestèle S, Schiavon E, Rusconi R, Franceschetti S, and Mantegazza M (2013) Nonfunctional NaV1.1 familial hemiplegic migraine mutant transformed into gain of function by partial rescue of folding defects. Proc Natl Acad Sci USA 110: 17546-17551.

Clark RB, Bouchard RA, and Giles WR (1996) Action potential duration modulates calcium influx, $\mathrm{Na}(+)-\mathrm{Ca} 2+$ exchange, and intracellular calcium release in rat ventricular myocytes. Ann N Y Acad Sci 779:417-429.

Clarke SG, Scarnati MS, and Paradiso KG (2016) Neurotransmitter release can be stabilized by a mechanism that prevents voltage changes near the end of action potentials from affecting calcium currents. $J$ Neurosci 36:11559-11572.

Clay JR (2013) A comparative analysis of models of $\mathrm{Na}^{+}$channel gating for mammalian and invertebrate nonmyelinated axons: relationship to energy efficient action potentials. Prog Biophys Mol Biol 111:1-7.

Collins CA and Rojas E (1982) Temperature dependence of the sodium channel gating kinetics in the node of Ranvier. $Q J$ Exp Physiol 67:41-55.

Covarrubias M, Barber AF, Carnevale V, Treptow W, and Eckenhoff RG (2015) Mechanistic insights into the modulation of voltage-gated ion channels by inhalational anesthetics. Biophys $J$ 109:2003-2011.

Engel D and Jonas P (2005) Presynaptic action potential amplification by voltage-gated $\mathrm{Na}+$ channels in hippocampal mossy fiber boutons. Neuron 45: 405-417.

Eskinder H, Supan FD, Turner LA, Kampine JP, and Bosnjak ZJ (1993) The effects of halothane and isoflurane on slowly inactivating sodium current in canine cardiac Purkinje cells. Anesth Analg 77:32-37.

Franks NP (2006) Molecular targets underlying general anaesthesia. Br J Pharmacol 147 (Suppl 1):S72-S81.

Fruscione F, Valente P, Sterlini B, Romei A, Baldassari S, Fadda M, Prestigio C, Giansante G, Sartorelli J, Rossi P, et al. (2018) PRRT2 controls neuronal excitability by negatively modulating $\mathrm{Na}+$ channel 1.2/1.6 activity. Brain 141: $1000-1016$.

Fujiwara N, Higashi H, Nishi S, Shimoji K, Sugita S, and Yoshimura M (1988) Changes in spontaneous firing patterns of rat hippocampal neurones induced by volatile anaesthetics. $J$ Physiol 402:155-175.

Goldin AL (2001) Resurgence of sodium channel research. Annu Rev Physiol 63: 871-894.

Graham B and Redman S (1994) A simulation of action potentials in synaptic boutons during presynaptic inhibition. J Neurophysiol 71:538-549.

Graham B, Wong AY, and Forsythe ID (2001) A computational model of synaptic transmission at the calyx of Held. Neurocomputing 34-40:37-42.

Hemmings HC Jr (2009) Sodium channels and the synaptic mechanisms of inhaled anaesthetics. $\mathrm{Br} J$ Anaesth 103:61-69.

Hemmings HC Jr, Akabas MH, Goldstein PA, Trudell JR, Orser BA, and Harrison NL (2005) Emerging molecular mechanisms of general anesthetic action. Trends Pharmacol Sci 26:503-510.

Herold KF and Hemmings HC Jr (2012) Sodium channels as targets for volatile anesthetics. Front Pharmacol 3:50.

Herold KF, Nau C, Ouyang W, and Hemmings HC Jr (2009) Isoflurane inhibits the tetrodotoxin-resistant voltage-gated sodium channel Nav1.8. Anesthesiology 111: 591-599.

Herold KF, Sanford RL, Lee W, Schultz MF, Ingólfsson HI, Andersen OS, and Hemmings HC Jr (2014) Volatile anesthetics inhibit sodium channels without altering bulk lipid bilayer properties. J Gen Physiol 144:545-560.

Herzog RI, Cummins TR, Ghassemi F, Dib-Hajj SD, and Waxman SG (2003) Distinct repriming and closed-state inactivation kinetics of Nav1.6 and Nav1.7 sodium channels in mouse spinal sensory neurons. J Physiol 551:741-750.

Herzog RI, Cummins TR, and Waxman SG (2001) Persistent TTX-resistant Na+ current affects resting potential and response to depolarization in simulated spinal sensory neurons. J Neurophysiol 86:1351-1364.

Hodgkin AL and Huxley AF (1952) A quantitative description of membrane current and its application to conduction and excitation in nerve. $J$ Physiol 117:500-544.

Hu W, Tian C, Li T, Yang M, Hou H, and Shu Y (2009) Distinct contributions of $\mathrm{Na}(\mathrm{v}) 1.6$ and $\mathrm{Na}(\mathrm{v}) 1.2$ in action potential initiation and backpropagation. Nat Neurosci 12:996-1002.

Jevtovic-Todorovic V (2016) General anesthetics and neurotoxicity: how much do we know? Anesthesiol Clin 34:439-451.

John VH, Main MJ, Powell AJ, Gladwell ZM, Hick C, Sidhu HS, Clare JJ, Tate S, and Trezise DJ (2004) Heterologous expression and functional analysis of rat Nav1.8 (SNS) voltage-gated sodium channels in the dorsal root ganglion neuroblastoma cell line ND7-23. Neuropharmacology 46:425-438.

Johnson KW, Herold KF, Milner TA, Hemmings HC Jr, and Platholi J (2017) Sodium channel subtypes are differentially localized to pre- and post-synaptic sites in rat hippocampus. J Comp Neurol 525:3563-3578.

Khaliq ZM, Gouwens NW, and Raman IM (2003) The contribution of resurgent sodium current to high-frequency firing in Purkinje neurons: an experimental and modeling study. J Neurosci 23:4899-4912.
Lai HC and Jan LY (2006) The distribution and targeting of neuronal voltage-gated ion channels. Nat Rev Neurosci 7:548-562.

Leffler A, Herzog RI, Dib-Hajj SD, Waxman SG, and Cummins TR (2005) Pharmacological properties of neuronal TTX-resistant sodium channels and the role of a critical serine pore residue. Pflugers Arch 451:454-463.

Lewis AH and Raman IM (2011) Cross-species conservation of open-channel block by $\mathrm{Na}$ channel $\beta 4$ peptides reveals structural features required for resurgent $\mathrm{Na}$ current. J Neurosci 31:11527-11536.

Lorincz A and Nusser Z (2008a) Cell-type-dependent molecular composition of the axon initial segment. J Neurosci 28:14329-14340.

Lorincz A and Nusser Z (2008b) Specificity of immunoreactions: the importance of testing specificity in each method. $J$ Neurosci 28:9083-9086.

Ogiwara I, Miyamoto H, Morita N, Atapour N, Mazaki E, Inoue I, Takeuchi T, Itohara S, Yanagawa Y, Obata K, et al. (2007) Nav1.1 localizes to axons of parvalbumin-positive inhibitory interneurons: a circuit basis for epileptic seizures in mice carrying an Scn1a gene mutation. $J$ Neurosci 27:5903-5914.

OuYang W and Hemmings HC Jr (2007) Isoform-selective effects of isoflurane on voltage-gated $\mathrm{Na}+$ channels. Anesthesiology 107:91-98.

Ouyang W, Herold KF, and Hemmings HC Jr (2009) Comparative effects of halogenated inhaled anesthetics on voltage-gated $\mathrm{Na}+$ channel function. Anesthesiology 110:582-590.

Ouyang W, Wang G, and Hemmings HC Jr (2003) Isoflurane and propofol inhibit voltage-gated sodium channels in isolated rat neurohypophysial nerve terminals. Mol Pharmacol 64:373-381.

Patel RR, Barbosa C, Xiao Y, and Cummins TR (2015) Human Nav1.6 channels generate larger resurgent currents than human Nav1.1 channels, but the Navß4 peptide does not protect either isoform from use-dependent reduction. PLoS One 10:e0133485.

Pinheiro PS and Mulle C (2008) Presynaptic glutamate receptors: physiological functions and mechanisms of action. Nat Rev Neurosci 9:423-436.

Pitt GS and Lee SY (2016) Current view on regulation of voltage-gated sodium channels by calcium and auxiliary proteins. Protein Sci 25:1573-1584.

Purtell K, Gingrich KJ, Ouyang W, Herold KF, and Hemmings HC Jr (2015) Activitydependent depression of neuronal sodium channels by the general anaesthetic isoflurane. Br J Anaesth 115:112-121.

Raatikainen MJ, Trankina MF, Morey TE, and Dennis DM (1998) Effects of volatile anesthetics on atrial and AV nodal electrophysiological properties in Guinea pig isolated perfused heart. Anesthesiology 89:434-442.

Raju SG, Barber AF, LeBard DN, Klein ML, and Carnevale V (2013) Exploring volatile general anesthetic binding to a closed membrane-bound bacterial voltage-gated sodium channel via computation. PLoS Comput Biol 9 e1003090.

Rehberg B, Xiao YH, and Duch DS (1996) Central nervous system sodium channels are significantly suppressed at clinical concentrations of volatile anesthetics. Anesthesiology 84:1223-1233; discussion 27A.

Rogers M, Zidar N, Kikelj D, and Kirby RW (2016) Characterization of endogenous sodium channels in the ND7-23 neuroblastoma cell line: implications for use as a heterologous ion channel expression system suitable for automated patch clamp screening. Assay Drug Dev Technol 14:109-130.

Sand RM, Gingrich KJ, Macharadze T, Herold KF, and Hemmings HC Jr (2017) Isoflurane modulates activation and inactivation gating of the prokaryotic $\mathrm{Na}^{+}$ channel NaChBac. J Gen Physiol 149:623-638.

Shiraishi M and Harris RA (2004) Effects of alcohols and anesthetics on recombinant voltage-gated Na+ channels. J Pharmacol Exp Ther 309:987-994.

Spruston N (2008) Pyramidal neurons: dendritic structure and synaptic integration. Nat Rev Neurosci 9:206-221.

Spurny R, Billen B, Howard RJ, Brams M, Debaveye S, Price KL, Weston DA Strelkov SV, Tytgat J, Bertrand S, et al. (2013) Multisite binding of a general anesthetic to the prokaryotic pentameric Erwinia chrysanthemi ligand-gated ion channel (ELIC). J Biol Chem 288:8355-8364.

Taheri S, Halsey MJ, Liu J, Eger EI 2nd, Koblin DD, and Laster MJ (1991) What solvent best represents the site of action of inhaled anesthetics in humans, rats, and dogs? Anesth Analg 72:627-634.

Tian C, Wang K, Ke W, Guo H, and Shu Y (2014) Molecular identity of axonal sodium channels in human cortical pyramidal cells. Front Cell Neurosci 8:297.

Westphalen RI and Hemmings HC Jr (2003a) Effects of isoflurane and propofol on glutamate and GABA transporters in isolated cortical nerve terminals. Anesthesiology 98:364-372.

Westphalen RI and Hemmings HC Jr (2003b) Selective depression by general anesthetics of glutamate versus GABA release from isolated cortical nerve terminals. $J$ Pharmacol Exp Ther 304:1188-1196.

Westphalen RI and Hemmings HC Jr (2006) Volatile anesthetic effects on glutamate versus GABA release from isolated rat cortical nerve terminals: 4-aminopyridineevoked release. J Pharmacol Exp Ther 316:216-223.

Westphalen RI, Kwak NB, Daniels K, and Hemmings HC Jr (2011) Regional differences in the effects of isoflurane on neurotransmitter release. Neuropharmacology 61:699-706.

Westphalen RI, Yu J, Krivitski M, Jih TY, and Hemmings HC Jr (2010) Regional differences in nerve terminal $\mathrm{Na}+$ channel subtype expression and $\mathrm{Na}+$ channel-dependent glutamate and GABA release in rat CNS. J Neurochem 113: 1611-1620.

Whitaker WR, Clare JJ, Powell AJ, Chen YH, Faull RL, and Emson PC (2000) Distribution of voltage-gated sodium channel alpha-subunit and beta-subunit mRNAs in human hippocampal formation, cortex, and cerebellum. J Comp Neurol 422: 123-139.

Whitaker WR, Faull RL, Waldvogel HJ, Plumpton CJ, Emson PC, and Clare JJ (2001) Comparative distribution of voltage-gated sodium channel proteins in human brain. Brain Res Mol Brain Res 88:37-53.

Wimmer VC, Harty RC, Richards KL, Phillips AM, Miyazaki H, Nukina N, and Petrou S (2015) Sodium channel $\beta 1$ subunit localizes to axon initial segments 
of excitatory and inhibitory neurons and shows regional heterogeneity in mouse brain. J Comp Neurol 523:814-830.

Wood JN and Baker M (2001) Voltage-gated sodium channels. Curr Opin Pharmacol 1:17-21.

Wu XS, Sun JY, Evers AS, Crowder M, and Wu LG (2004) Isoflurane inhibits transmitter release and the presynaptic action potential. Anesthesiology 100: 663-670.

Yan H, Wang C, Marx SO, and Pitt GS (2017) Calmodulin limits pathogenic $\mathrm{Na}+$ channel persistent current. J Gen Physiol 149:277-293.

Zhang Y, Guzinski M, Eger EI 2nd, Laster MJ, Sharma M, Harris RA, and Hemmings HC Jr (2010) Bidirectional modulation of isoflurane potency by intrathecal tetrodotoxin and veratridine in rats. $\mathrm{Br} J$ Pharmacol 159: 872-878.

Zhang Y, Sharma M, Eger EI 2nd, Laster MJ, Hemmings HC Jr, and Harris RA (2008) Intrathecal veratridine administration increases minimum alveolar concentration in rats. Anesth Analg 107:875-878

Address correspondence to: Dr. Hugh C. Hemmings, Jr., Departments of Anesthesiology and Pharmacology, Weill Cornell Medicine, New York, NY 10065. E-mail: hchemmi@med.cornell.edu 